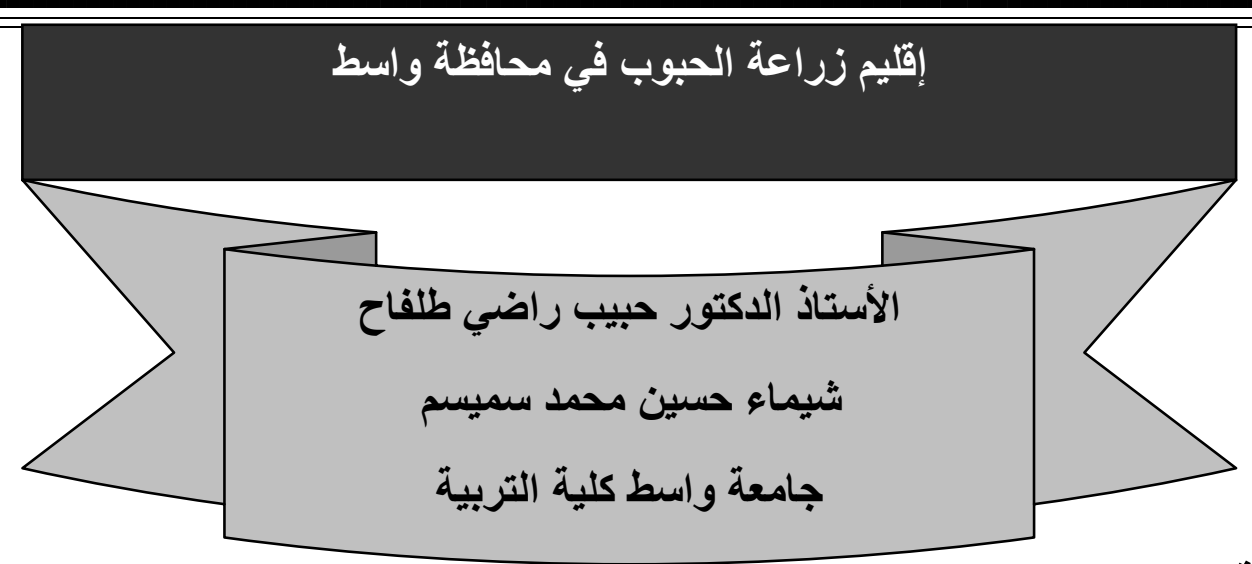

المقدمة

إن دراسة الأقاليم الزر اعية لمكان ما تعد عملية مهمة في فهم تضافر العوامل الطبيعية

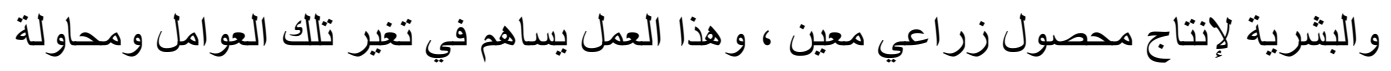
التحكم بها في المستقبل . حيث تشغل هذه المحاصيل مساحات جغر افية تتباين سعة وموقعاً مكانياً مكونة أقاليم زر اعية تعكس علاقات مكانية تسبغ على أماكن وجودها سمة معينة تميز ها عما هاهي

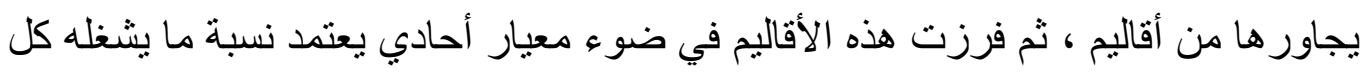

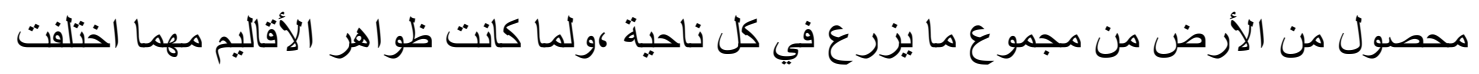

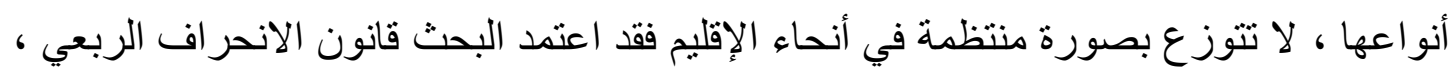
للكثف عن صورة تدرج الظاهرة في كل إقليم. ويمكن صياغة مشكلة البحث على الثكل التساؤل الآتي :- ما هو نمط التوزيع المكاني لإقليم

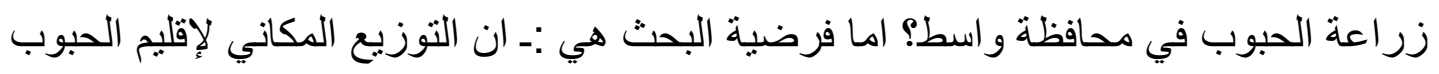

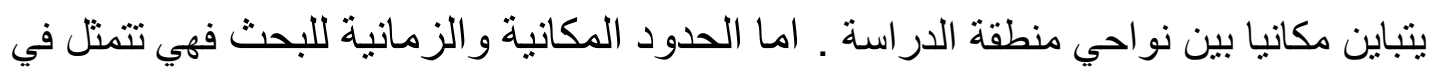

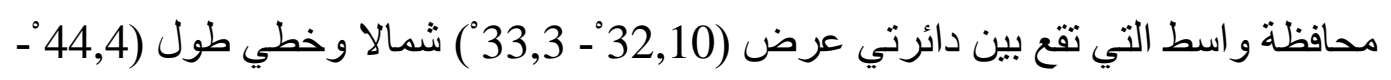

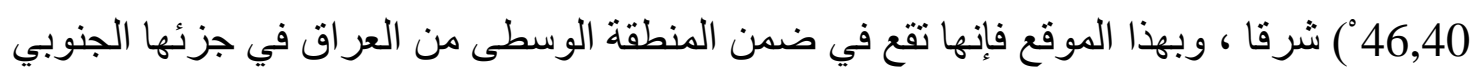

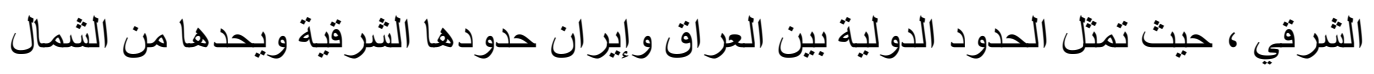

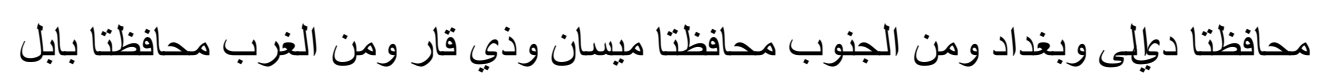

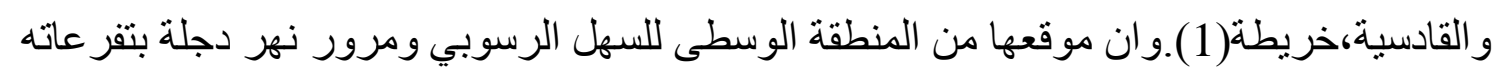
من خلالها ساهم في ظهور أقاليم زر اعية عدة مختلفة فيها. 
تبلغ مساحتها (17153 كم2) أي ما نسبته (3,9\%) من المجموع الكلي لمساحة العر اق البالغة

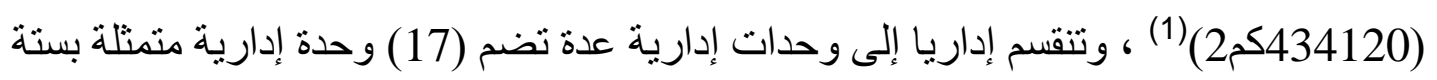

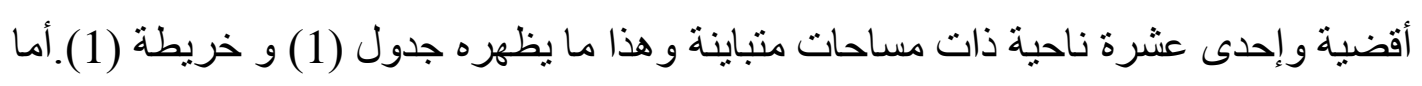

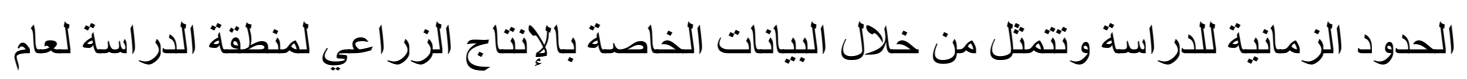

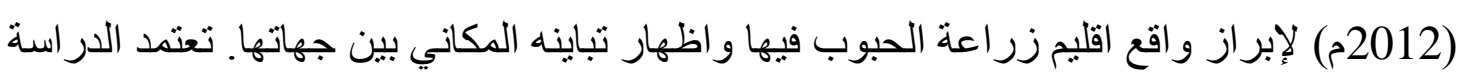

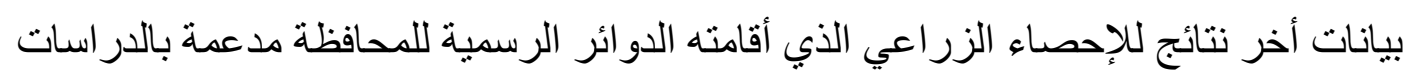

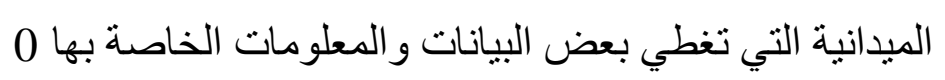




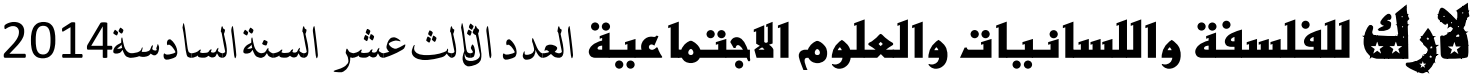

خريطة (1)

موقع محافظة و اسط من العراق حسب وحداتها الادارية

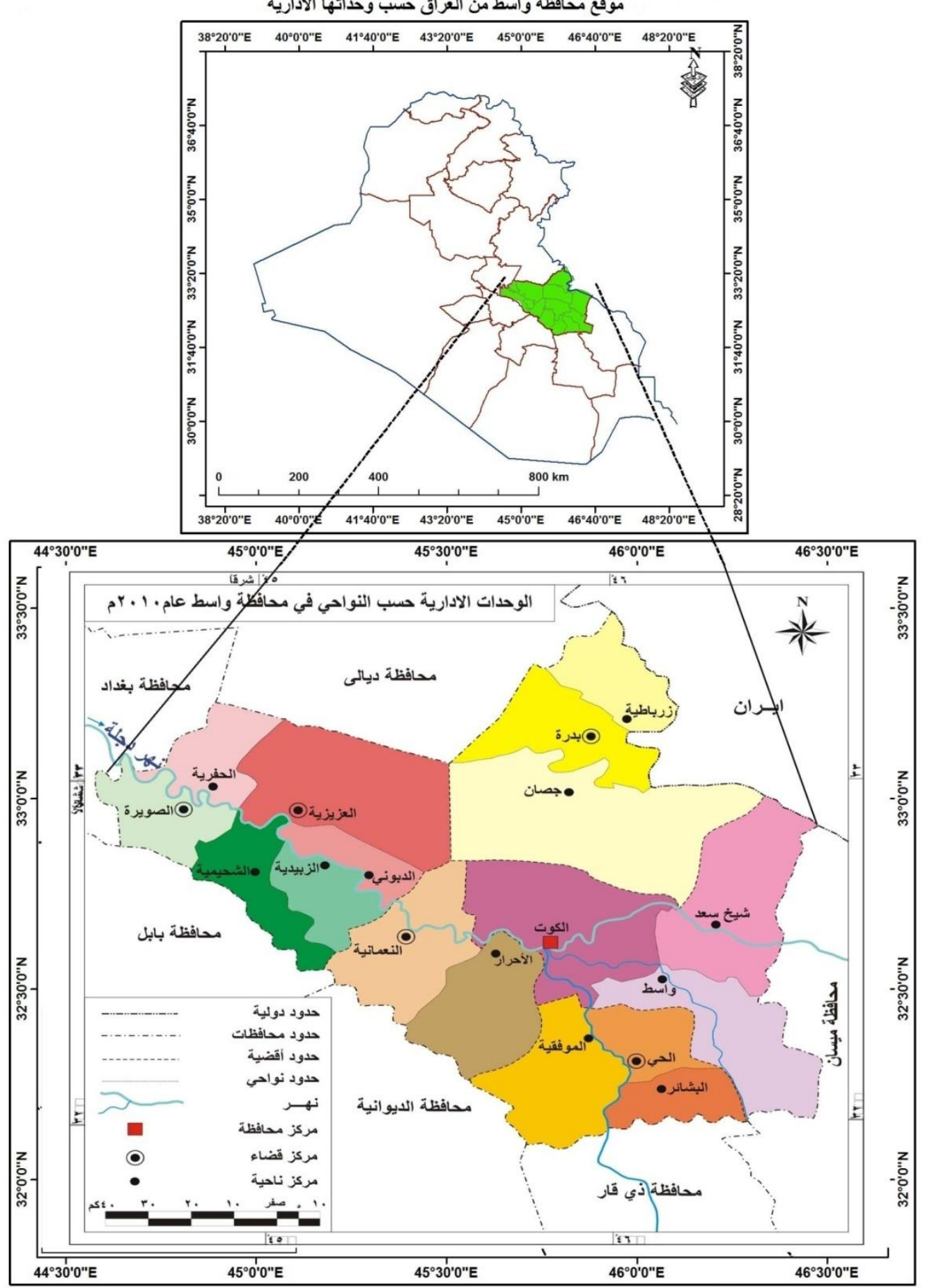

المصدر:- الهيأة العامة للمساحة ،خريطة العراق الإدارية، بغداد ،2010 .

ـ الهيأة العامة للمساحة ،خريطة محافظة و اسط الإدارية، بغداد 2010 


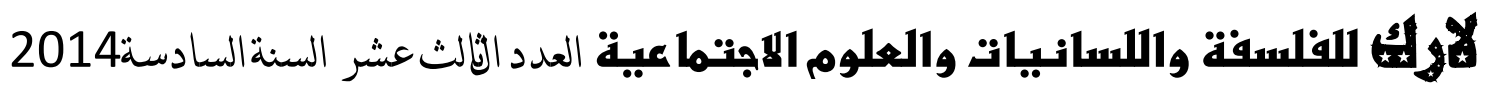

جدول (1)الوحدات الإدارية في محافظة واسط

\begin{tabular}{|c|c|c|}
\hline المساحة / كم & المساحة / دونم & الوحدات الإدارية \\
\hline 2540 & 688799 & كز قضاء الكوت \\
\hline 1841 & 707000 & ية واسط \\
\hline 763 & 703044 & +ناحية شيخ سعد \\
\hline 946 & 412875 & مركز قضاء النعمانية \\
\hline 1170 & 507000 & لية الأحرار \\
\hline 404 & 88337 & مركز قضاء الحي \\
\hline 1085 & 424110 & ناحية الموفقية \\
\hline 510 & 312400 & ناحية البشائر \\
\hline 1214 & 368358 & مركز قضاء بدرة \\
\hline 1856 & 798280 & ناحية جصان \\
\hline 580 & 295396 & ناحية الذهب زرباطية \\
\hline 508 & 243693 & مركز قضاء الصويرة \\
\hline 432 & 284638 & ناحية الزبيدية \\
\hline 540 & 120120 & ناحية الثحيمية \\
\hline 1402 & 466456 & مركز قضاء العزيزية \\
\hline 345 & 218346 & ناحية الحفرية \\
\hline 720 & 390318 & ناحية الدبوني \\
\hline 17153 & 7029170 & المجموع \\
\hline
\end{tabular}


المصدر :- جمهورية العراق ، وزارة التخطيط والتعاون الإنمائي،الجهاز المركزي للإحصاء وتكنولوجيا 0 المعلومات ، بيانات غير منشورة ، 2012 تشغل محافظة واسط نسبة متقدمة من بين محافظات البلاد الأخر و لاسيما في محاصيل الحبوب

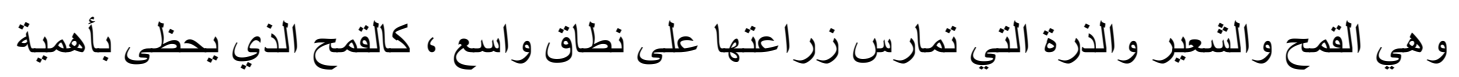

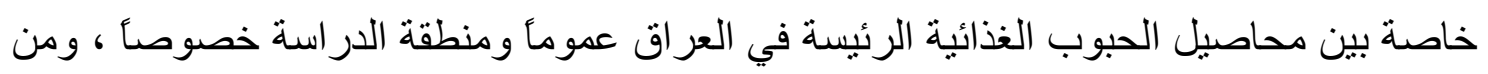

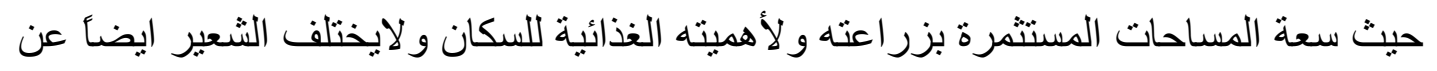

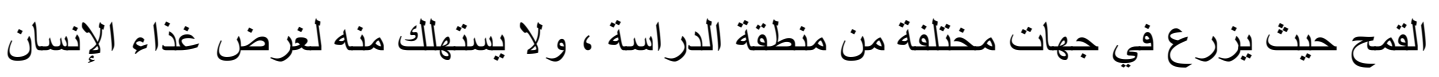
إلا القليل ، فغالبيته يطرح للبيع في الأسواق كمحصول تجاري في أو يستهلاتك كعلف حيو اني ، أما محصول الذرة فتتنشر زر اعته في أنحاء عدة من منطقة الدراسة لزيادة الطلب عليه كونه يدخل مادة أساسية في علف الدواجن وصناعة الزيوت النباتية .

وسنتناول التحليل الجغر افي لإقليم القمح أو لا لأهميته الواضحة بالنسبة للححافظة والعراق 0

$$
1 \text { - إقليم القمح :- }
$$

يُعد القمح من النباتات العشبية الحولية وينتمي إلى العائلة النجيلية ( Gramineae) و الجنس (Triticum) يزرع شتاء وهو من المحاصيل الستر اتيجية التي تدخل في غذاء الإنسان

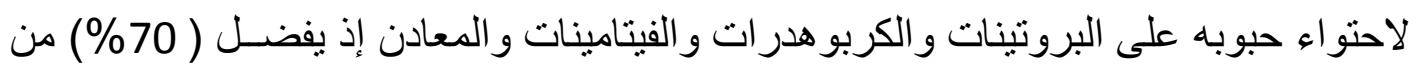
ســكان العالم الخبز المصنوع من دقيقه الذبي يولد طاقة حر ارية تتراوح بين( 2000 - 2500)

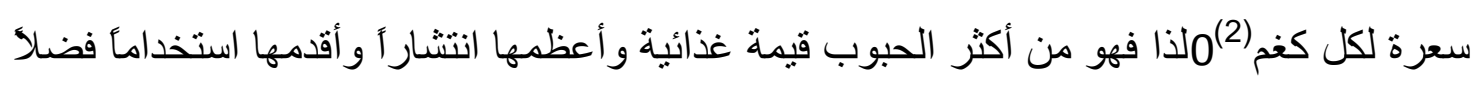
عن دخوله كمادة أولية في الصناعة واستعمال قثنه علفأ للحيو انات ،وتتركز زر اعته في المناطق المعتلة الدافئة(3) ، ويتطلب القمح حر ارة دنيا وقصوى تختلف باختلاف أطوار النمو ، وتمثل

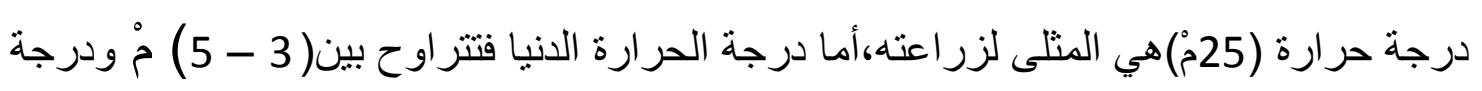
الحر ارة القصوى تتزاوح بين (23 - 30) مُ ، وبذلك فإن المحصول يحتاج إلى ( 2330 (230) وحدة

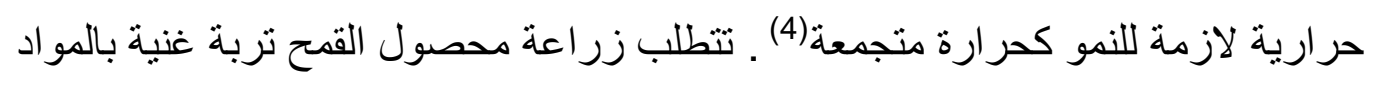

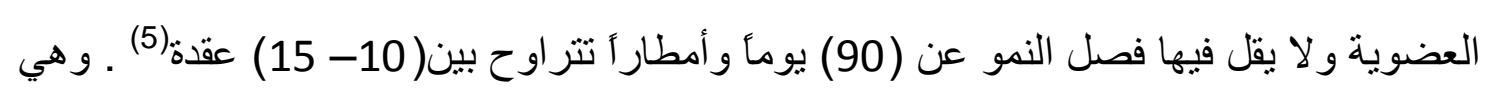
تسقط في معظم أنحاء منطقة الدر اسة فقد بلغ المعدل السنوي للأمطار (118) ملم ، و لا تسد كمية 
الأمطار هذه التي تسقط في منطقة الدراسة حاجة المحصول المائية لذا فهو يعتمد على مياه الري

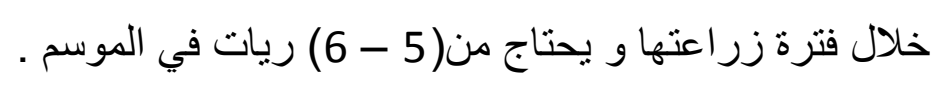

وتبدأ زر اعة محصول القمح خلال شهر تشرين الثاني حتى منتصف كانون الأول ليتيح له

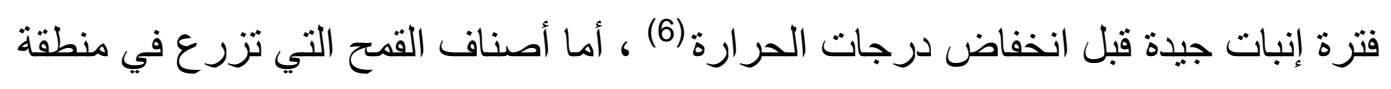
الدراسة هي المكسيباك ذو الارتفاع المتوسط و الساق الغليظة ومقاومة الاضطباع داع والإنتاجية

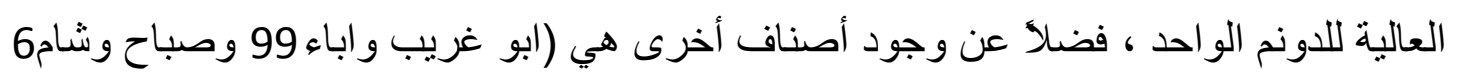

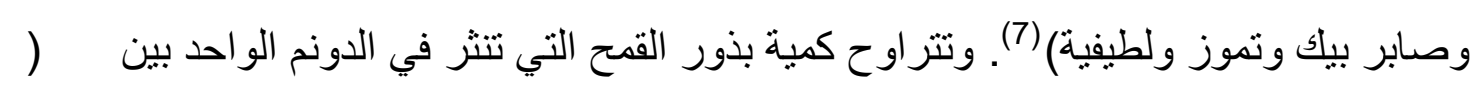

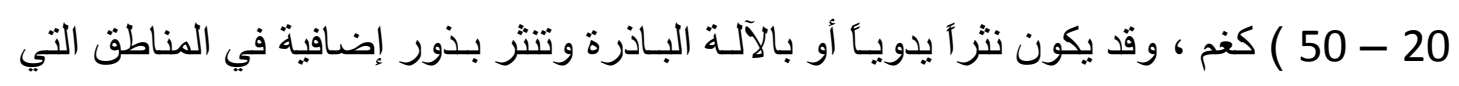
يفتل فيها الإنبات وتسمى بعملية الترقيع (8)

أما التربة الملائمة لزر اعة محصول القمح في منطقة الدراسة فتشغل جانبي نهر دجلة حيث

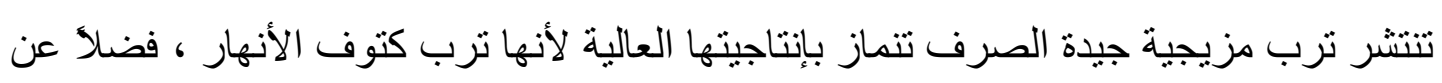

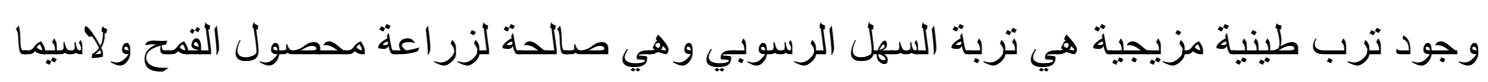

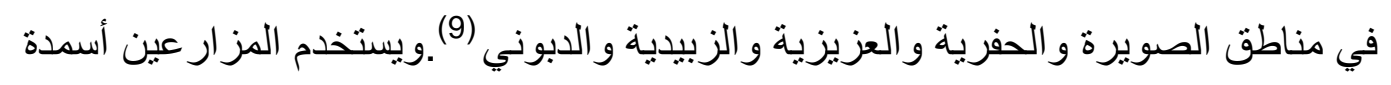
كيمياوية لسد نقص حاجة التربة من مو اد غير عضوية حيث يضاف لكل دونم بين (60-

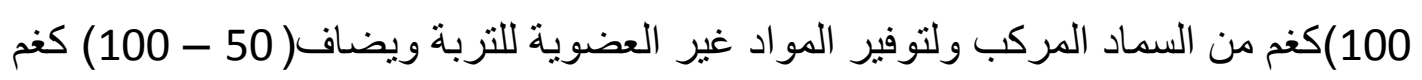

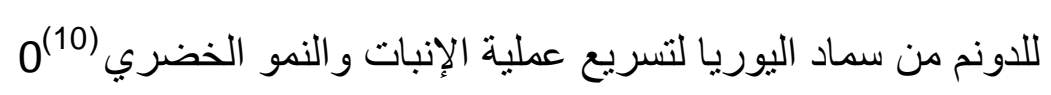

ويتم تحضير الأرض لزر اعة المحصول في أو ائل فصل الخريف تحديداً في بداية شهر

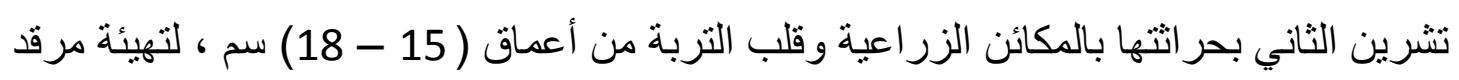

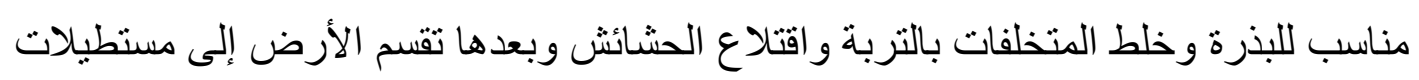

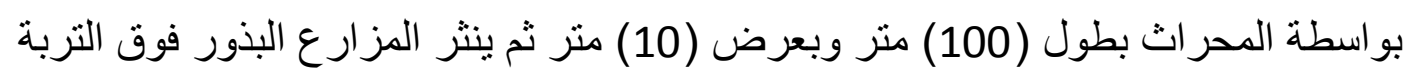

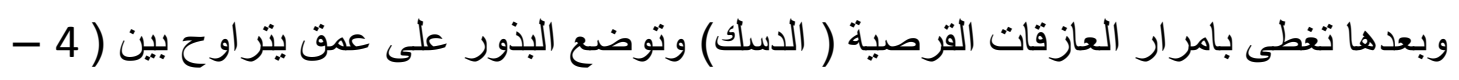

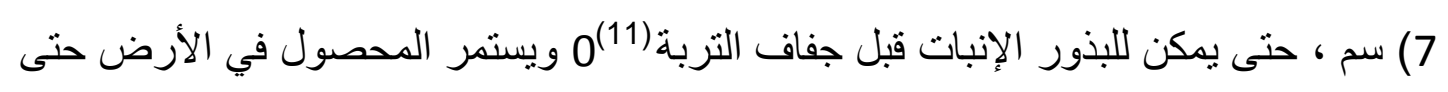
نهاية فصل الربيع ليتم نضجه ،ويحتاج المحصول إلى كمية من مياه الري من وقت بذاره حتى لإنى 
حصاده ما يعادل (350) ملم ، و إذا سقطت الأمطار خلال فترة النمو فانه يساعد على تقليص عدد

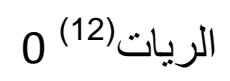

وزار عة محصول القمح ناجحة في منطقة الدر اسة لأنها توفر بيئة مناسبة لنموه حيث نو عية

التربة المزيجية و المتثملة في كتوف الأنهار ومزيجية طينية متمثلة بتربة السهل الرسوبي وتوفر

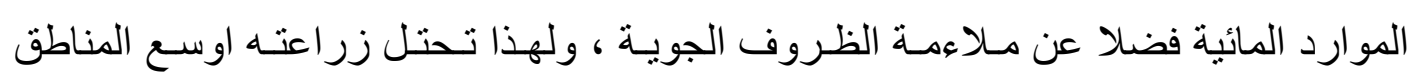
الزر اعية في منطقة الدر اسة ،حيث تبلغ مساحة الأراضي التي تزرع بمحصول القمح ( 663631) دونم سنة 2012 (13) . جدول(2) ونؤلف ما نسبته (71,07\%) من مجموع المساحات المزروعة. وقد زاد الاهتمام بزر اعته في منطقة الدر اسة في السنوات الأخيرة لتشجيع الدولة على زر اعته من خلال دعم أسعاره التسويقية مما ساهم في زر اعة مساحات واسعة من الأر اضي غير المزروعة

للاستفادة منها 0

وللكثف عن طبيعة نوزيع إقليم القمح في منطقة الدراسة اعتمدت تقنية الانحر اف المعياري البالغة (25,13) درجة وهي تقل عن قيمة الوسط الحسابي البالغة ( 61,48\%) و هذا بعني أن هنالك تبايناً مكانياً في نسب المساحات المخصصة لزر اعة هذا المحصول بين جهات منطقة الدر اسة المختلفة ويظهر جدول (3) خريطة (2) التوزيع الربعي للمساحات المزروعة بالقمح طبيعة هذا التوزيع واتجاهاته المكانية ، و عند تطبيق قانون الانحر اف الربعي أتاح لنا تصنيف منطقة الدر اسة إلى أربع فئات تظهر خريطة (2) توزيعها الجغر افي وبالثكل الاتي

جدول (2)محاصيل الحبوب الرئيسية في محافظة واسط لسنة 2012 *

\begin{tabular}{|c|c|c|}
\hline النسبة \% & / الدساحة المزروعة & المحاصيل \\
\hline 71,07 & 663631 & القمح \\
\hline 22,12 & 206473 & الشعير \\
\hline 6,81 & 63547 & الذرة \\
\hline$\% 100$ & 933651 & المجموع \\
\hline
\end{tabular}


يظهر توزيع هذا الربع في منطقة واسعة من المحافظة ويأخذ نمطأ جغر افيا واضحأ بشغل

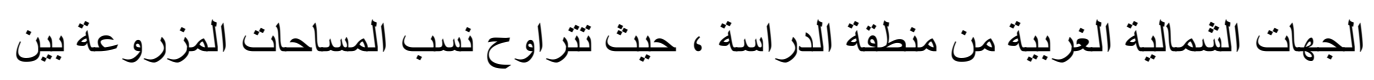

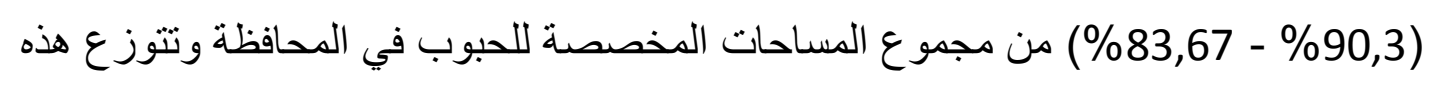

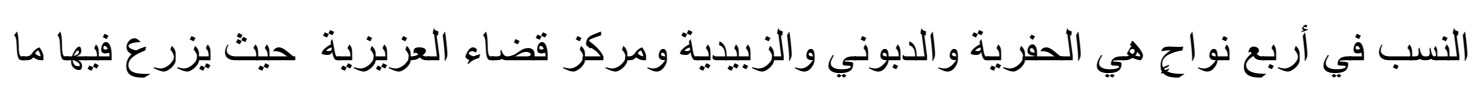

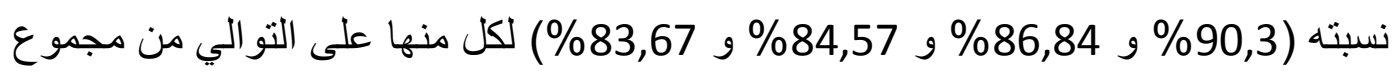

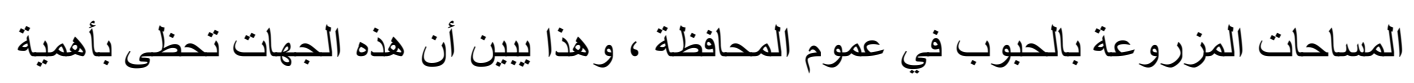

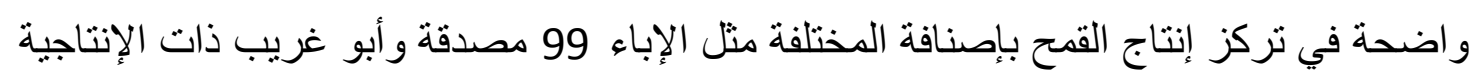
0 العالية 0

وتتر اوح كميات الإنتاج في هذا الربع ما بين ( 95,2\% - 86,29\%) إذ سجلت ناحية

الثحيمية أعلى النسب للإنتاج بواقع (95,2\%) على الرغم من أنها احتلت المرتبة الثالثة من

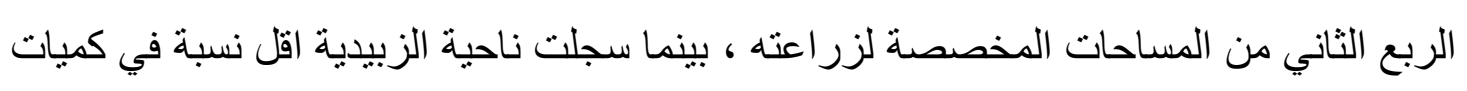

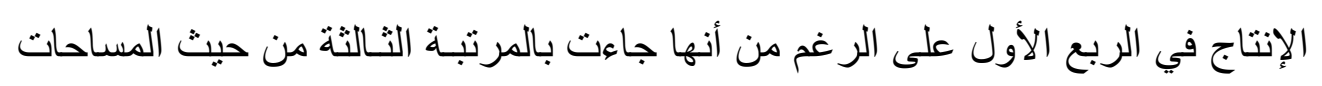

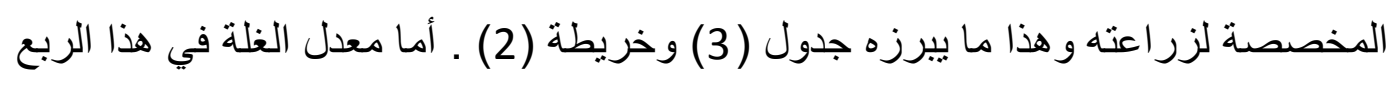

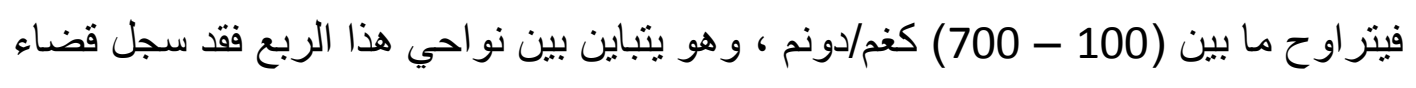

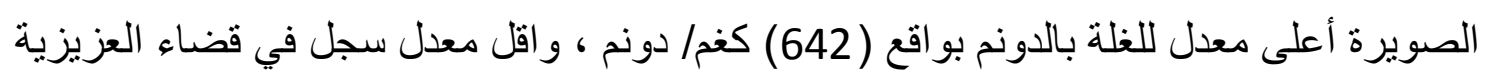

$$
\text { بو اقع (400) كغم / دونم (14) }
$$


التوزيع الربعي للمساحات المزروعة بالقمح سنة 2012

\begin{tabular}{|c|c|c|c|c|c|c|c|}
\hline النسبة \% & المزنمة المساحة | & الوحدة الإدارية & & النسبة * \% & المزنم المساحة & الوحدة الإدارية & \\
\hline 63,9 & 12475 & جصان & \multirow{4}{*}{$\begin{array}{l}\overline{3} \\
\overline{3} \\
\overline{3}\end{array}$} & 90,3 & 66969 & الحفرية & \multirow{4}{*}{$\begin{array}{l}\overline{3} \\
\overline{2} \\
\bar{\jmath}\end{array}$} \\
\hline 61,14 & 50395 & النعمانية & & 86,84 & 37311 & الدبوني & \\
\hline 59,48 & 39755 & الكوت & & 84,57 & 68000 & الزبيدية & \\
\hline 45,78 & 3665 & بدرة & & 83,67 & 65724 & العزيزية & \\
\hline 35,61 & 11960 & الموفقية & \multirow{4}{*}{$\begin{array}{l}\overline{3} \\
\overline{\overline{3}}\end{array}$} & 82,43 & 115000 & الأحر ار & \multirow{4}{*}{$\begin{array}{l}\overline{3} \\
\overline{2} \\
\overline{3}\end{array}$} \\
\hline 30,96 & 14550 & شيخ سعد & & 78,99 & 56674 & الصويرة & \\
\hline 18,81 & 3400 & الحي & & 74,72 & 68000 & الثحيمية & \\
\hline 14,02 & 1936 & البشائر & & 72,39 & 47817 & و اسط & \\
\hline
\end{tabular}

المصدر : مديرية زر اعة واسط ، قسم الإحصاء ، بيانات غير منشورة ، 2012 


\section{خريطة (r)}

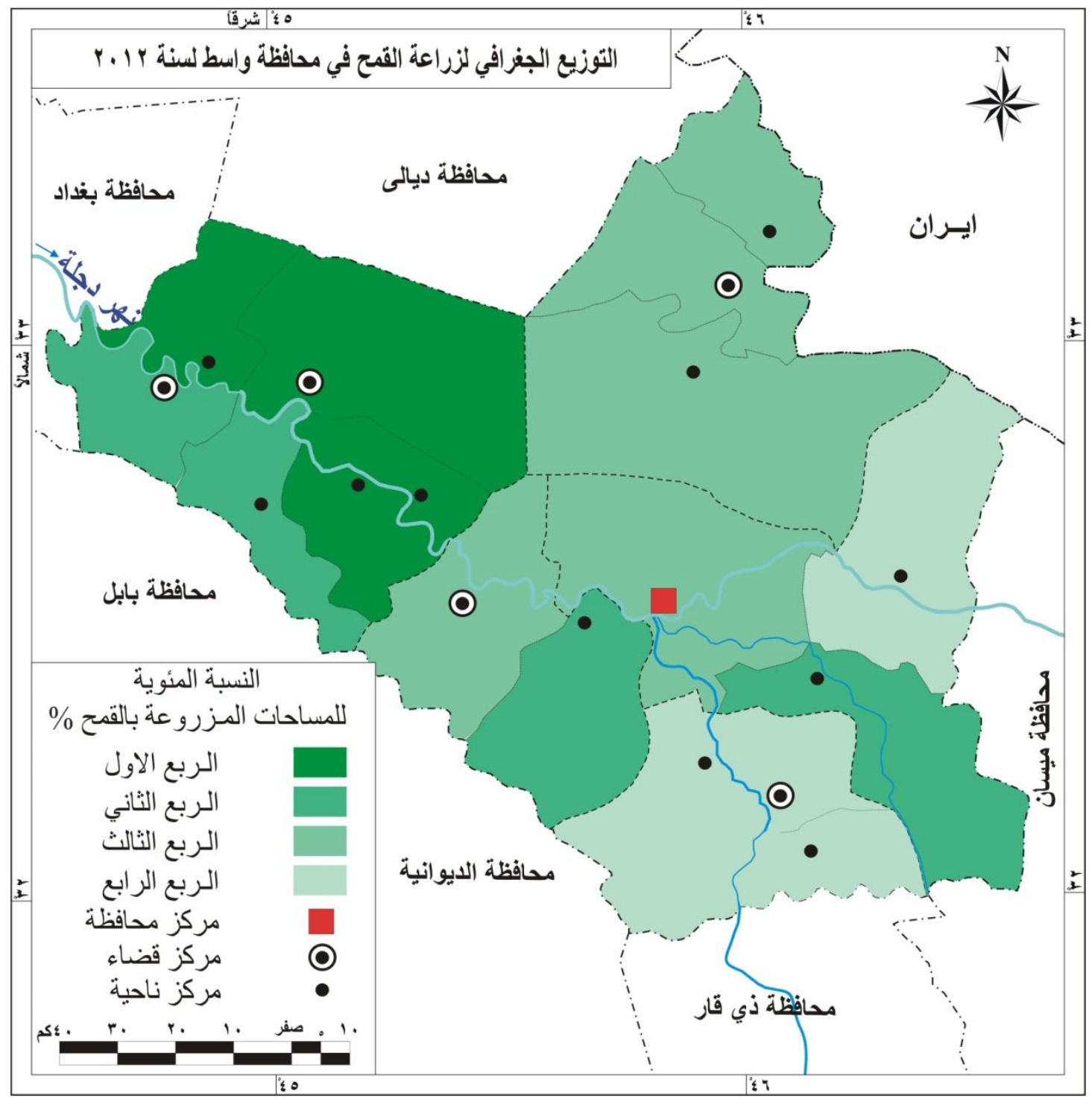

المصدر : مديرية زر اعة واسط ، قسم الإحصاء ، بيانات غير منشورة ، 2012. الريع الثاني :-

تتوزع المساحات المخصصة لزر اعة القمح في هذا الربع في أربع نواح،هي: الأحرار ومركز

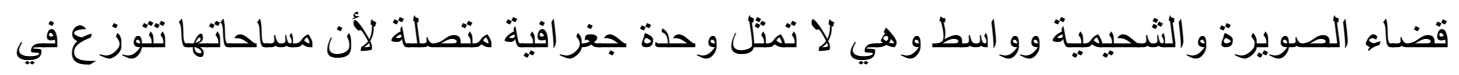

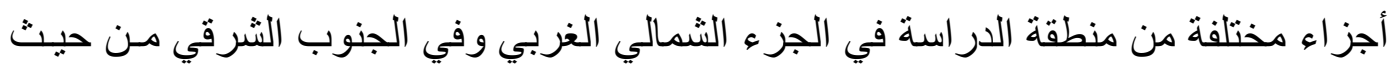

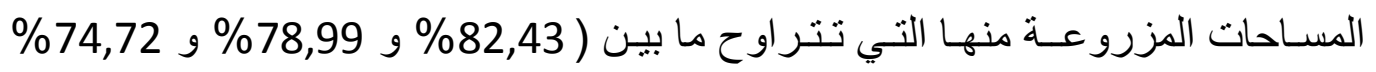


و72,39\%) على التوالي من المساحات المخصصة لزر اعة الحبوب فيها أما بالنسبة لكميات الإنتاج فهي تتراوح ما بين (72,62\% - 85,12\%) وقد سجلت ناحية الدبوني أعلى نسبة بو اقع (85,12) وسجلت ناحية جصان أقل نسبة بو اقع ( 72,62\%) في هذا الربع ،ومما يلاحظ على ذلك أن نواحي مساحات الربع الثاني تختلف عن نواحي الربع نفسه لكميات الإنتاج فناحية الدبوني

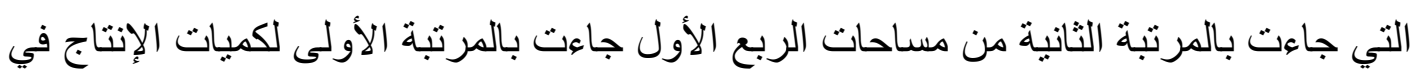

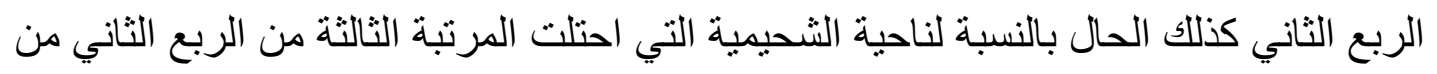

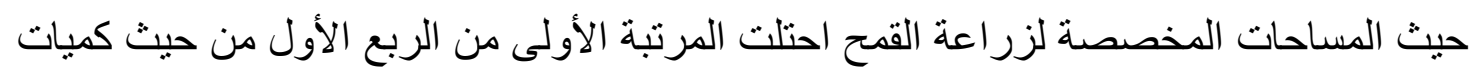

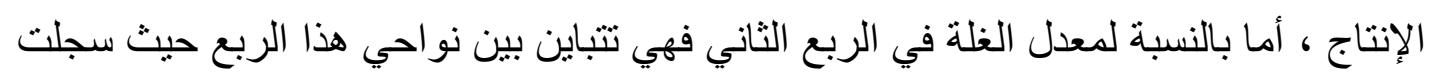

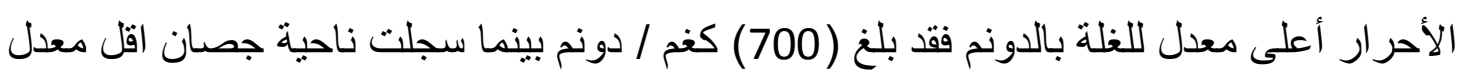

$$
\text { غلة بو اقع (347) كغم / دونم (15) الاحرئ }
$$

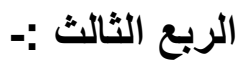

تأخذ المساحات الزر اعية لمحصول القمح بالقلة تدريجيأ في أربع نواح أخرى حيث

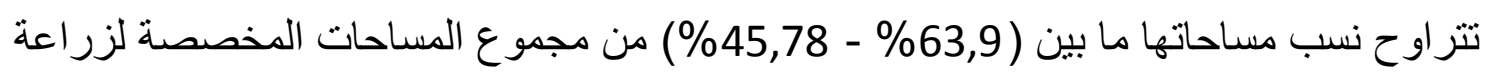

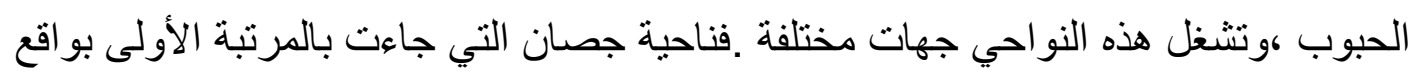

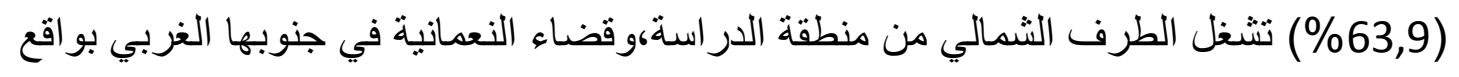

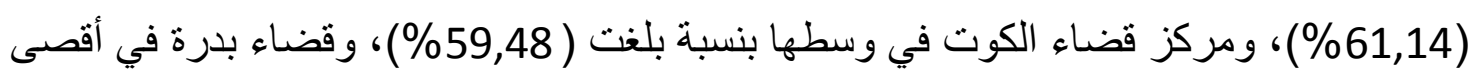

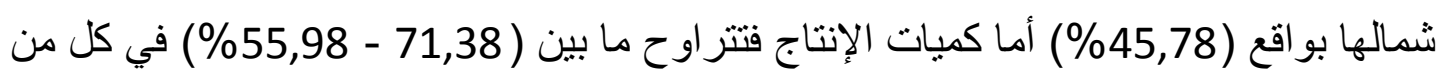

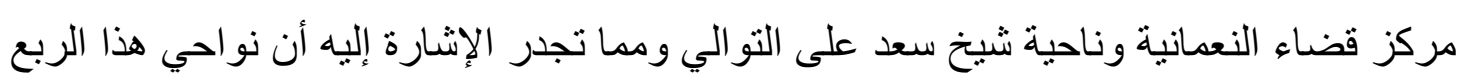

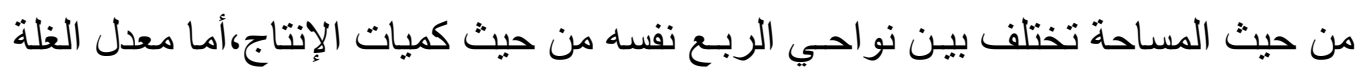

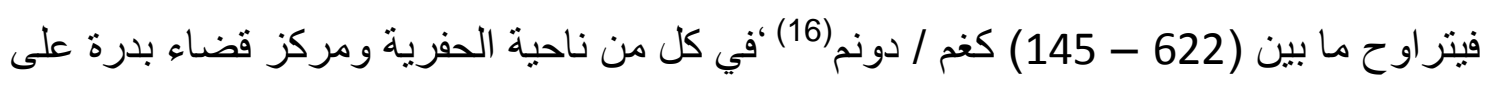
التو الي.

جدول (4) التوزيع الربعي لكميات إنتاج القمح حسب نو احي منطقة الدراسة 


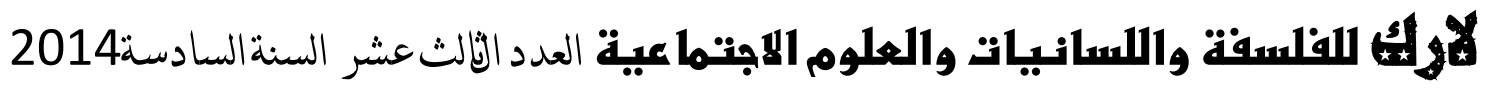

\begin{tabular}{|c|c|c|c|c|c|c|c|}
\hline النسبة \% & |المساحة & الوحدة الإدارية & & النسبة \% & |لمزئمة المزروعة & الوحدة الإدارية & \\
\hline 71,38 & 17335,88 & النعمانية & \multirow{4}{*}{$\begin{array}{l}\overline{3} \\
\overline{3} \\
\overline{3}\end{array}$} & 95,2 & 47600 & الشحيمية & \multirow{4}{*}{$\begin{array}{l}\overline{3} \\
\bar{y} \\
\bar{\jmath}\end{array}$} \\
\hline 69,43 & 23336,185 & الكوت & & 91,45 & 36384,708 & الصويرة & \\
\hline 61,96 & 41655,5 & تاج الدين & & 87,08 & 26289,6 & العزيزية & \\
\hline 55,98 & 4365 & شيخ سعد & & 86,29 & 23800 & الزبيدية & \\
\hline 477,06 & 624,35 & بدرة & \multirow{4}{*}{$\begin{array}{l}\overline{3} \\
\overline{3} \\
\overline{2}\end{array}$} & 85,12 & 18655,5 & الدبوني & \multirow{4}{*}{$\begin{array}{l}\overline{3} \\
\overline{3} \\
\overline{3}\end{array}$} \\
\hline 27,34 & 1700 & الحي & & 82,34 & 28212,03 & و اسط & \\
\hline 13,90 & 580,8 & البشـائر & & 80,90 & 80500 & الأحر ار & \\
\hline 5,30 & 4784 & الموفقية & & 72,62 & 4336,25 & جصـان & \\
\hline
\end{tabular}

المصدر : مديرية زر اعة واسط ، قسم الإحصاء ، بيانات غير منشورة ، 2012 
خريطة (r)

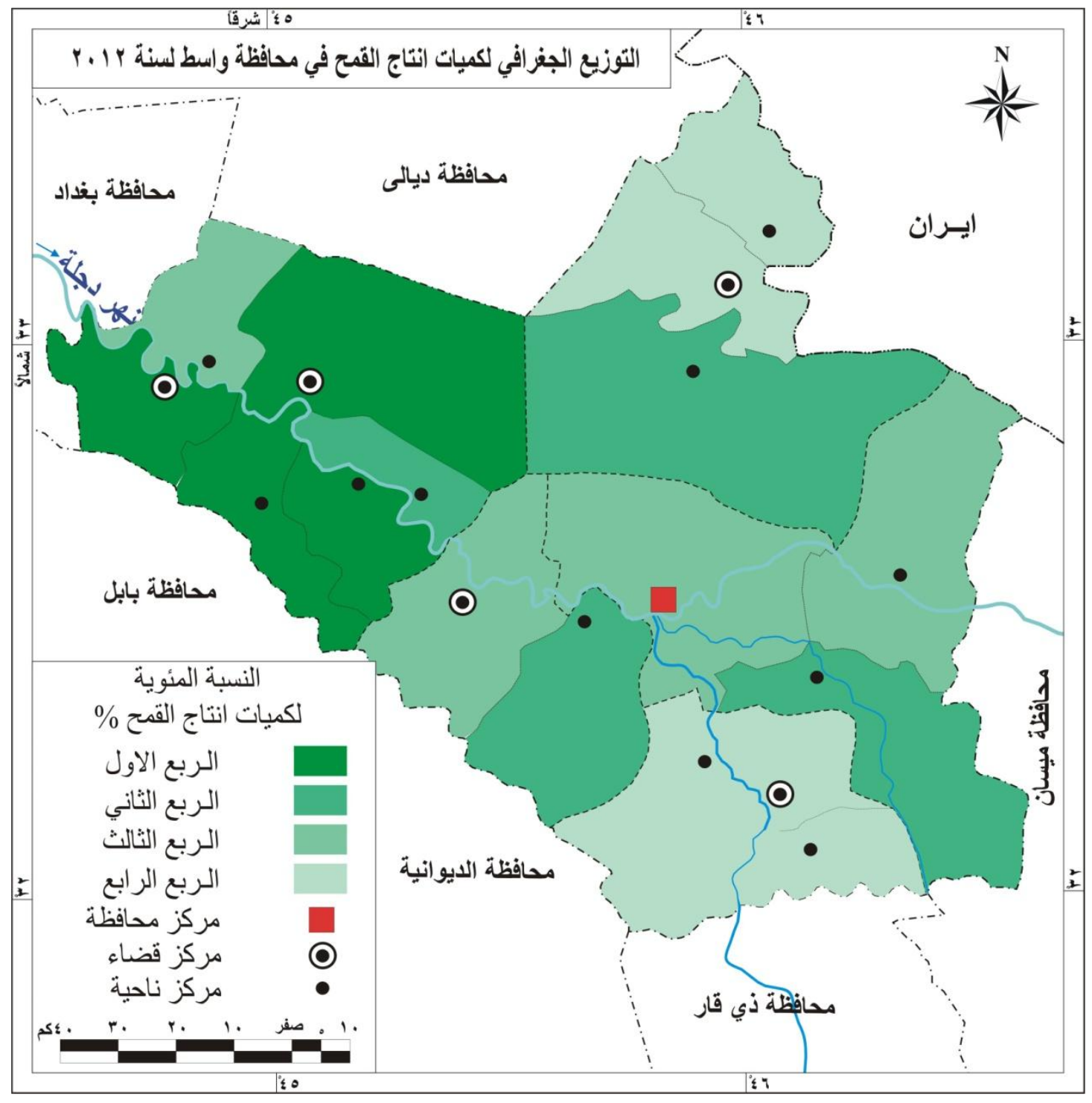

المصدر : مديرية زر اعة واسط ، قسم الإحصاء ، بيانات غير منشورة ، 2012

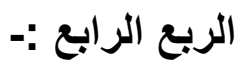

يظهر هذا الربع في جهات و اسعة من منطقة الدراسة حيث يضم كلا من ناحية الموفقية في جنوبها الغربي وناحية شيخ سعد في شرقها ومركز قضاء الحي وناحية البشائر في جنوبها وان لهان

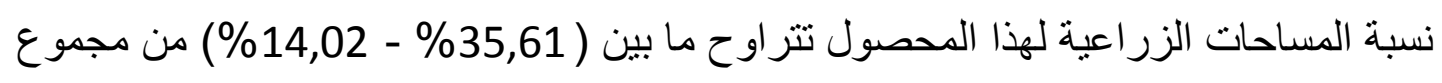
المساحات المزروعة بالحبوب ويعكس توزيع هذا الربع تراجعأ واضحاً في زر اعة القمح لصالح 
زر اعة محاصيل أخرى كالثعير و الذرة ـ ويؤكد هذه الحقيقة حقيقة أخرى كونها جهات هي الأقل

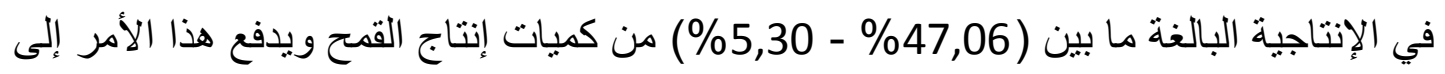

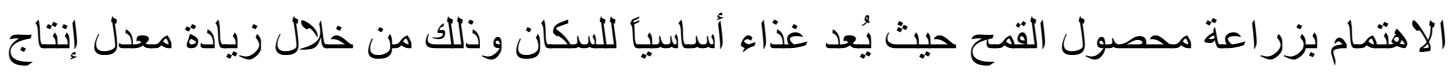
الغلة الذي يتر اوح ما بين (500 - 145) كغم/دونم (17)

ويظهر مما تقدم أن إقليم القمح في منطقة الدر اسة تسود زر اعته الجهات الثمالية و الثمالية الغربية ويأخذ بالقلة كلما اتجهنا نحو المناطق الجنوبية و الثرقية في نواحي الموفقية وناحية شيخ سعد وقضاء الحي وناحية البشائر حيث شهدت قلة واضحة في المساحات الزراعية وانتاجية القمح وفي معدل الغلة 0 2 - إقليم محصول الشعير :-

يمثل محصول الثعير واحدأ من محاصيل الحبوب الثتوية أسوة بالقمح حيث ينتمي إلى هـ العائلة النجيلية (Gramineae) و الى الجنس (Hordeum) ووتنتشر جذوره جانبيا في التربة بين

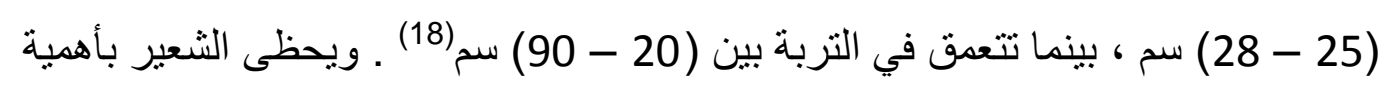

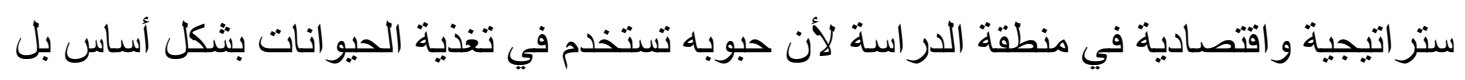

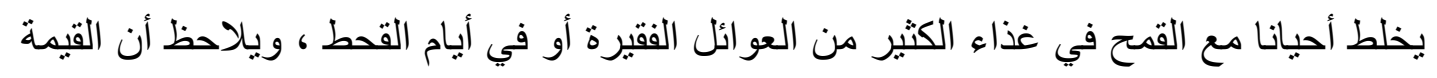

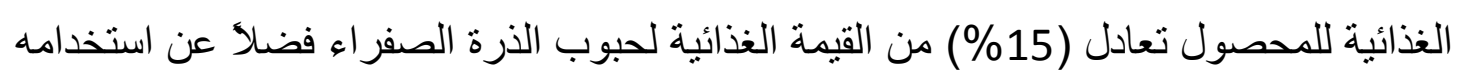
في المجال الصناعي(19).

نتيجة تدهور الظروف البيئية مثل انعدام الأمطار أو شحة مياه الري احيانأ تستخدم المساحات

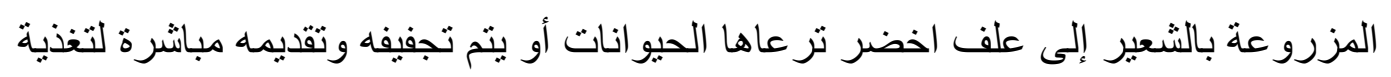

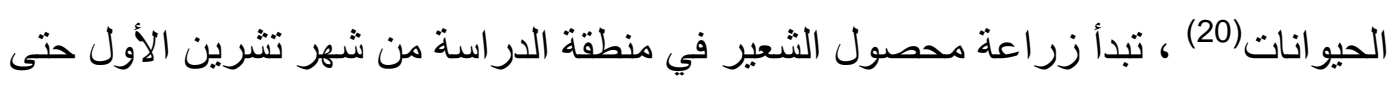

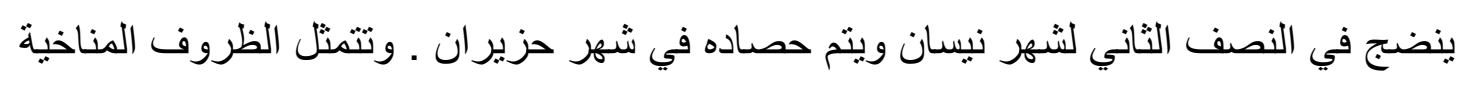

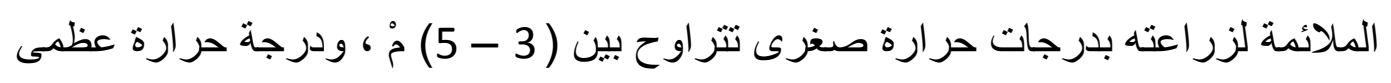

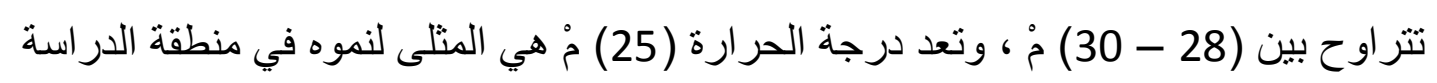
خاصة و العراق عامة ،ويحتاج المحصول طيلة فصل نموه إلى ( 1858) وحدة حر ارية كحر ارة الهي متجمعة(21) 
ويتطلب محصول الثعير من (5 - 6) ريات خلال موسم النمو وبالنسبة للتربة فانه يمكن زر اعته في الترب الرملية أو القلوية وانه يعطي حاصلا أعلى في الترب المزيجية الخصبة الجيدة الصرف ذات التفاعل الأيوني (PH 7-6) ،ويُعد أكثر مقاومة لملوحة التربة مقارنة بالقمح إلا أنه

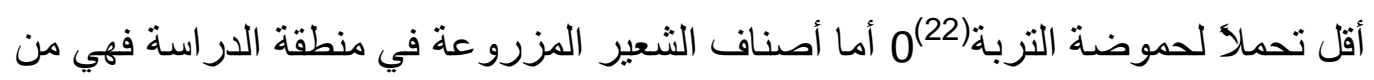
الصنف الأبيض المحلي ذو الساق القوية وهو منوسط الارتفاع وله القابلية العالية على تحمل الملوحة،وتتزر اوح كمية البذور المستخدمة لزر اعة الدونم الواحد (20 - 25 ) كغم (23). ويتم تحضير الأرض لزر اعة الدحصول بو اسطة الآلات للحر اثة وتتثر البذور فوق التربة وبعدها لتوريا

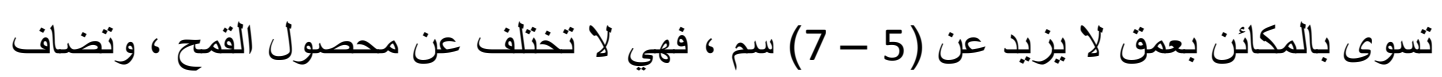

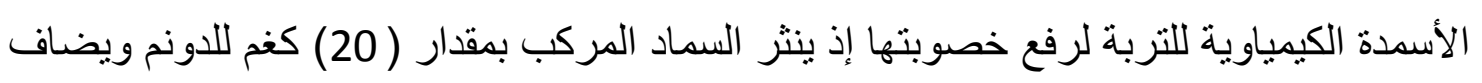

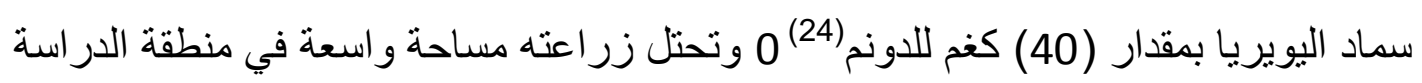

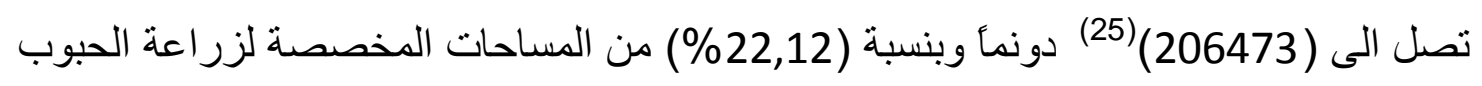
و هذا يعني أن زر اعته تأتي بالمرتبة الثانبة بعد القمح وذللك لملاءمة الظروف الطبيعية و البشرية

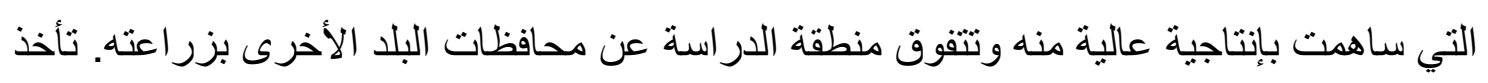

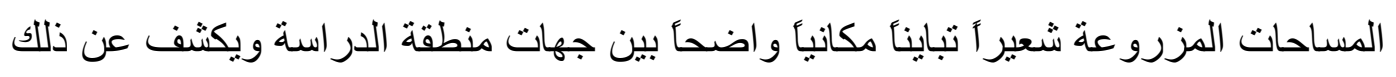
درجة الانحر اف المعياري البالغة (28,4) وهي تقترب عن قيمة الوسط الحسابي البالغ

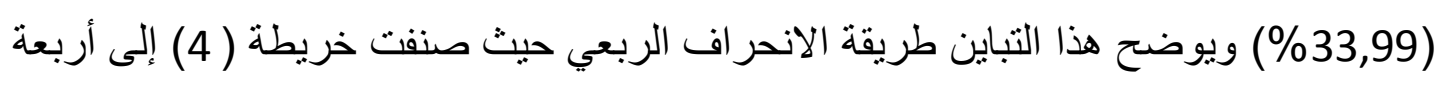

$$
\begin{aligned}
& \text { أرباع جدول (5) و هي على الثكل الآتي :- }
\end{aligned}
$$

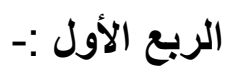

يحتل هذا الربع رقعة جغر افية تكاد يتصل بعضها بيعض في الأجز اء الجنوبية الثرقية من

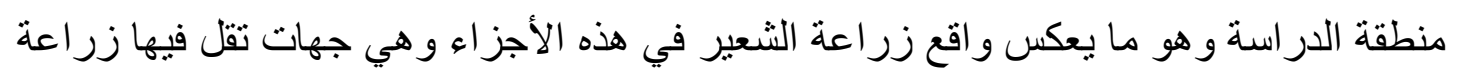

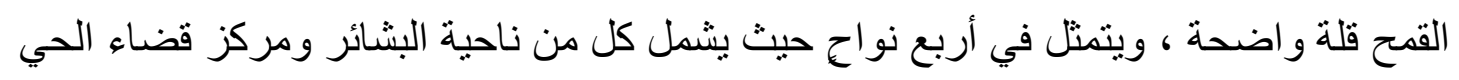

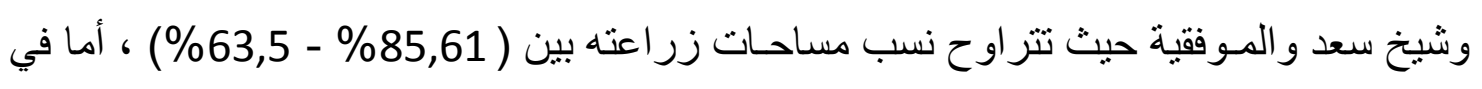
كميات الإنتاج فتظهر أن ناحية شيخ سعد هي الوحيدة بين نواحي هذا الربع التي جاءت في الربع

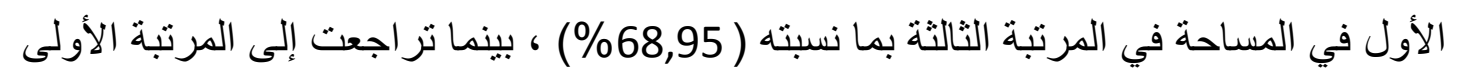


من الربع الثاني من حيث كميات الإنتاج بعد أن سجلت نسبة بلغت (43,63\%) انظر جدول (6) (15) وخريطة (5) وقد سجل هذا الربع كميات انتاج غلة تتر اوح ما بين (400 - 135) كغم / دونم 0

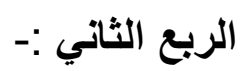
تتوزع المساحات المخصصة لزر اعة الثعبر في هذا الربع في أربع نواج هي بدرة

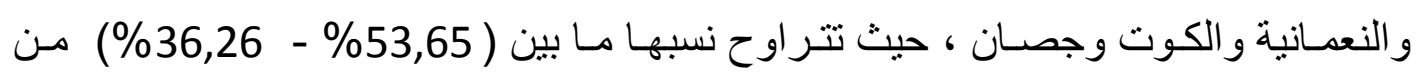

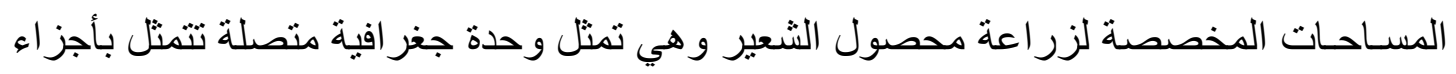
مختلفة في منطقة الدراسة ، ففي مركز قضاء بدرة التي تقع في أقصى الثمال الثرقي سجلت نسبة مساحة بلغت $(53,65)$ وفي قضاء النعمانية في الأجز اء الغربية سجلت نسبة مساحة فركاء

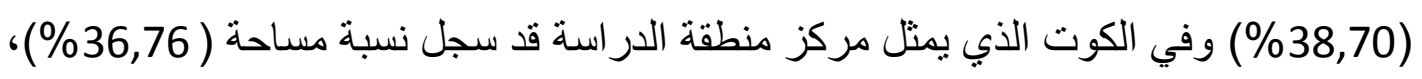
وناحية جصان في الجزء الثمالي منها قد سجلت نسبة مساحة ( 1 (36,26\%) ، وتنتباين هذه النواحي ايضأ في كميات إنتاجها فتتر اوح نسب كميات إنتاج هذا الربع ما بين ( 43,63\% - 26,10\% في كل من شيخ سعد والكوت على التو الي ويتراوح معدل الغلة لإنتاج محصول الثعير في هذا

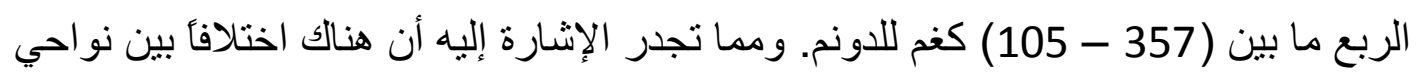
الربع الثاني من حيث المساحة وكميات الإنتاج 0

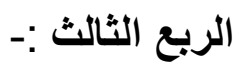

تأخذ نسب المساحات المخصصة لزر اعة محصول الثعير في هذا الربع بالانخفاض

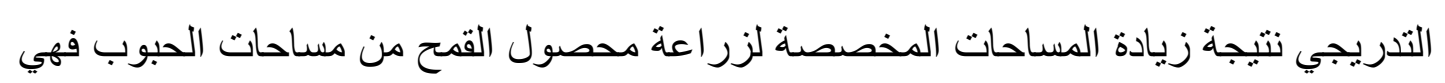

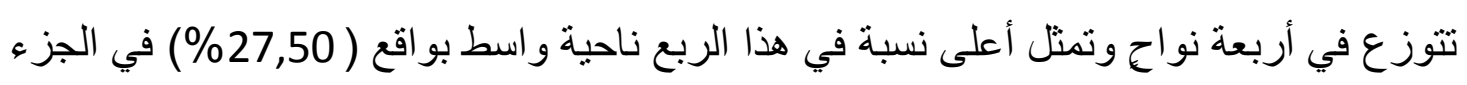

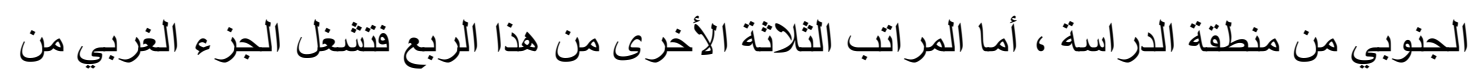

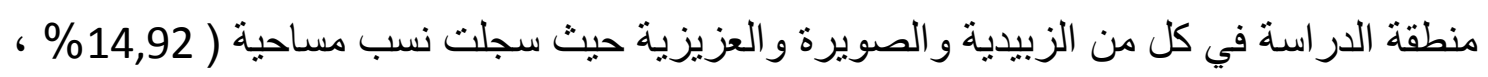

12,56\% ، 10,66\%) من مجموع المساحة المزرو عة بالحبوب على التو الي ، أما كميات الإنتاج في هذا الربع فتكاد تكون متشابهه في توزيعها الجغر افي لنو احي مساحات الإنتاج باستثناء قضاء العزيزية الذي جاء بالمرتبة الثانية من الربع الأخير لإنتاج الثعبر لتصعد ناحية لتونية الأحرار 
إلى الربع الثالث من حيث الإنتاج بينما كانت تحتل المرتبة الأخيرة من حيث المساحة حيث تراوحت نسب كميات الإتتاج بهذا الربع ما بين ( 17,49\% - 7,53\%) ، ومما بلاحظ على ذلك

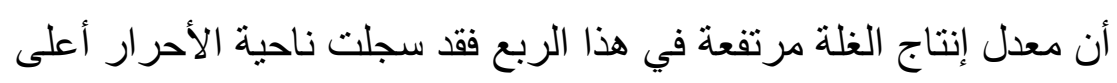

جدول (5)التوزيع النسبي للمساحات المزرو عة بالثعير حسب نو احي منطقة الدراسة لسنة 2012

\begin{tabular}{|c|c|c|c|c|c|c|c|}
\hline النسبة \% & المزروعة المساحة & الالودرية & & النسبة \% & المزروعة المساحة & الإدارية & \\
\hline 27,50 & 18166 & و واسط & $\overline{3}$ & 85,61 & 11818 & البشائر & $\overline{3}$ \\
\hline 14,92 & 12000 & الزبيدية & 哥 & 78,02 & 14100 & الحي & $\begin{array}{l}\bar{\lambda} \\
\text { Jे }\end{array}$ \\
\hline 12,56 & 9016 & الصويرة & & 68,95 & 32400 & شيخ سعد & \\
\hline 10,66 & 8375 & العزيزية & & 63,5 & 21321 & الموفقية & \\
\hline 7,33 & 3150 & الدبوني & $\overline{3}$ & 53,65 & 4295 & بدرة & $\overline{3}$ \\
\hline 5,1 & 3780 & الحفرية & $\frac{\overline{3}}{2}$ & 38,70 & 31900 & النعمانية & 哥 \\
\hline 3,29 & 3000 & الشحيمية & & 36,76 & 24572 & الكوت & \\
\hline 1,07 & 1500 & الأحر ار & & 36,26 & 7080 & جصان & \\
\hline
\end{tabular}

المصدر : مديرية زر اعة واسط ، قسم الإحصاء ، بيانات غير منشورة ، 2012 
خريطة (؛)

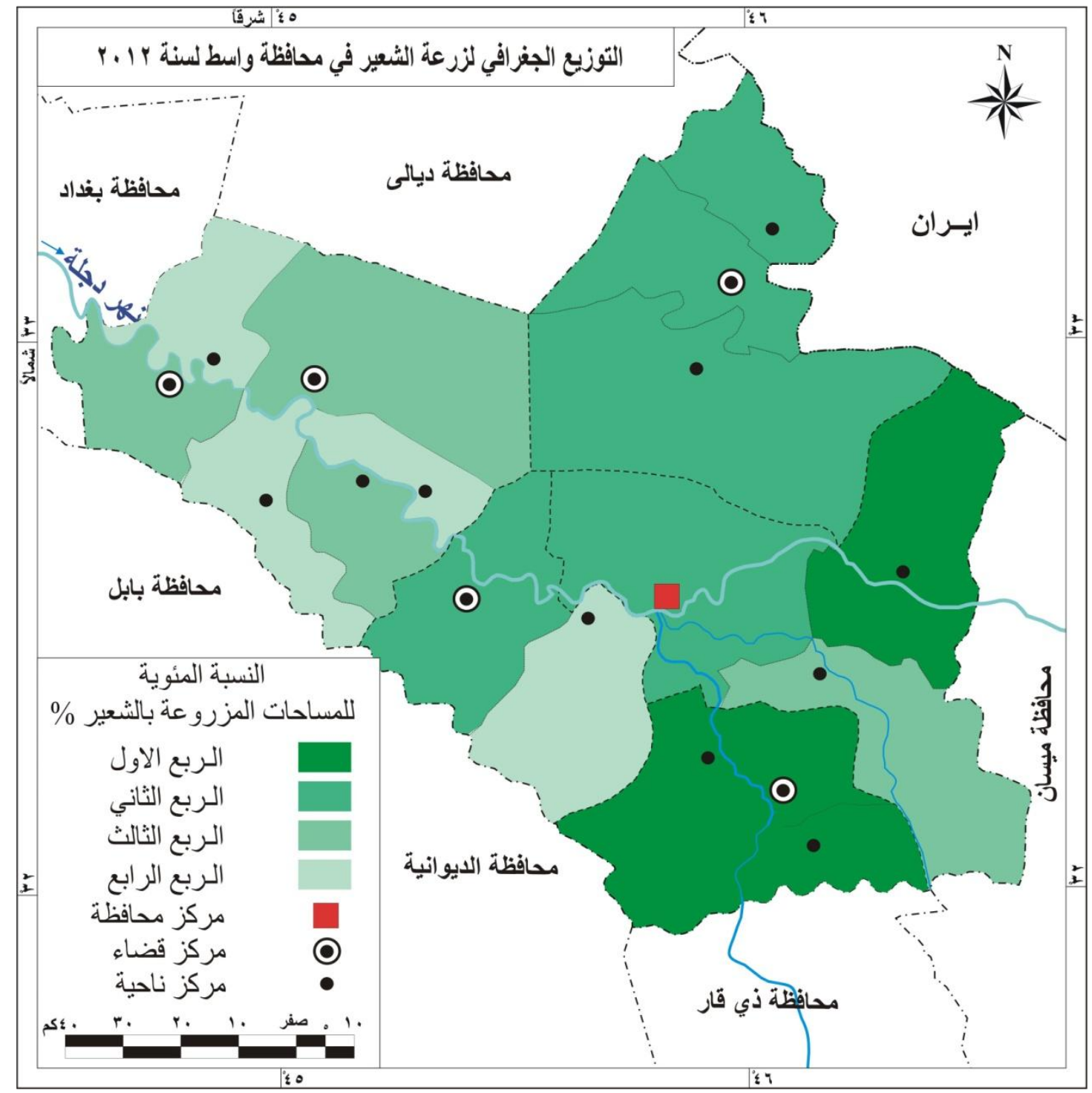

المصدر : مديرية زر اعة و اسط ، قسم الإحصاء ، بيانات غير منشورة ، 2012.

معدل غلة لإنتاج الثعير في المحافظة بواقع (500) كغم / دونم وناحية الزبيدية اقل معدل إنتاج في هذا الربع بو اقع (300) كغم / دونم 0

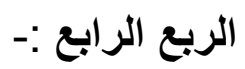


المساحات المخصصة لزر اعة الثعير في هذا الربع هي اقل جهات منطقة الدراسة، وتتمثل في

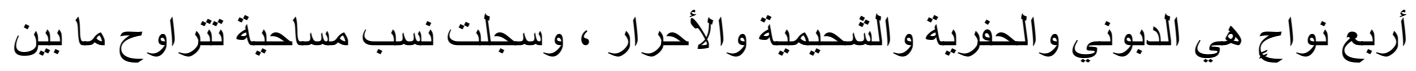

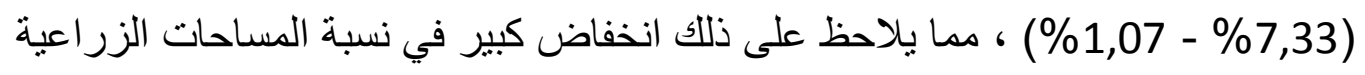

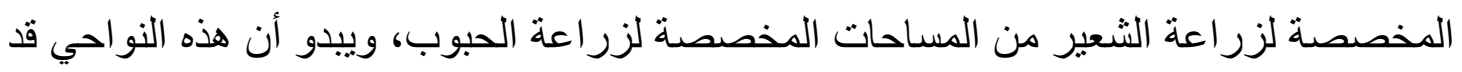

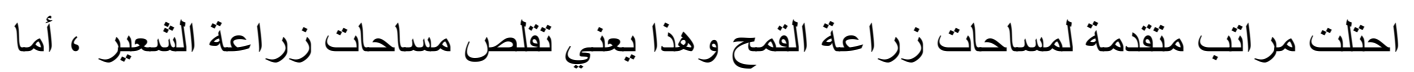
كميات انتاجه فقدً كانت منخفضة ايضأ للنو احي نفسها وهي تتز اوح ما بين ( 5,74\% - 1,90\%)

من حيث كميات الإنتاج على الرغم من أن هنالك ارتفاعأ في إنتاجية الغلة لهذه النواحي التي لهي تتراوح ما بين (400- 200) كغم / دونم قياسأ بغلات إنتاج الربع الثناني و الثالث.

و هذا يعني أن هناك تبايناً مكانياً واضحأ في المساحات المخصصة لزر اعة الثعير ويظهر لنا

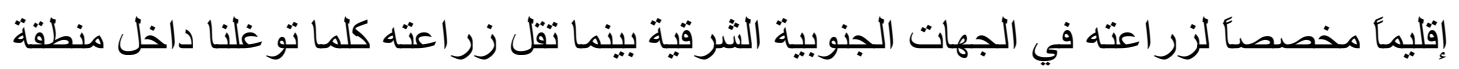

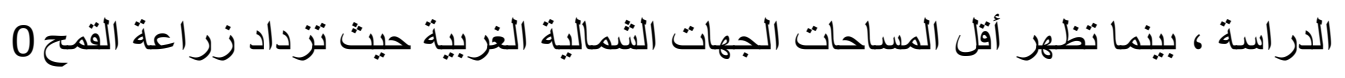
3 -إقليم الأرة :-

يُعد محصول الذرة من المحاصيل الصيفية المهمة التي يعتمد عليها الإنسان في غذائه، كما

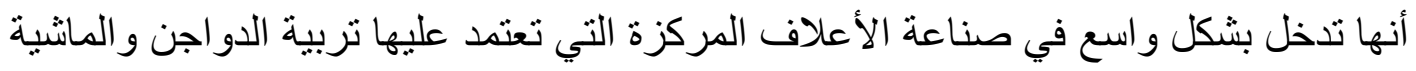

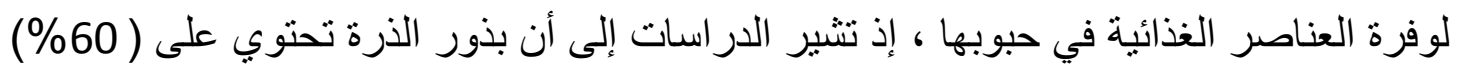
نشا و(10\%) بروتين و (30\%) زيوت(26). ينطلب هذا المحصول درجة حرارة نتراوح بين (30 - 32) مُ ، ويجب ان لاتقل في مرحلة الإنبات عن (10) مُ ، لأن درجات الحرارة الواطئة

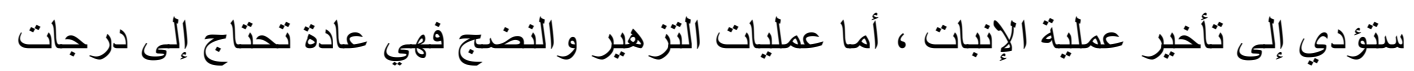
حر ارة مرتفعة نو عأ ما ، و الى ساعات طويلة من السطوع الثمسي و لاسيما في وقت النهار النهار (27) .

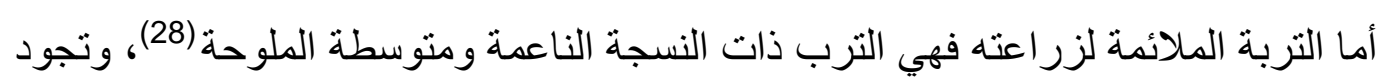

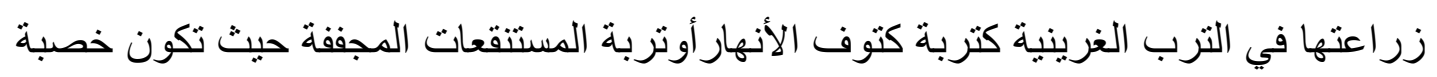

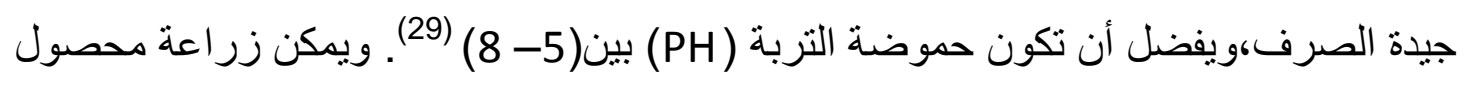

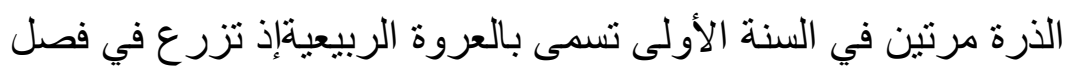




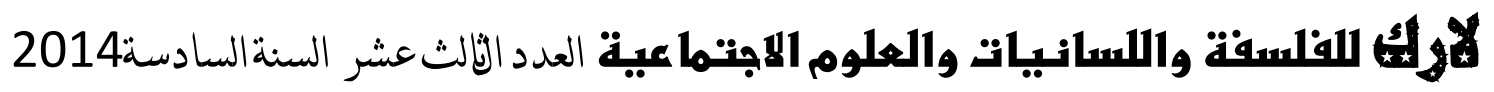

جدول (6)

التوزيع الربعي لكميات إنتاج الثُعير حسب نو احي منطقة الدراسة لسنة 2012

\begin{tabular}{|c|c|c|c|c|c|c|c|}
\hline النسبة \% & المزروعة المساحة & الوحدة الإدارية & & النسبة \% & المزروعة المساحة & الوحدة الإدارية & \\
\hline 17,49 & 5994,78 & و واسط & \multirow{4}{*}{$\begin{array}{l}\overline{3} \\
\overline{3} \\
\overline{3}\end{array}$} & 94,59 & 85284 & الموفقية & \multirow{4}{*}{$\begin{array}{l}\overline{\overline{3}} \\
\overline{\bar{z}} \\
\bar{\jmath}\end{array}$} \\
\hline 13,05 & 3600 & الزبيدية & & 84,89 & 3545,4 & البشـائر & \\
\hline 7,70 & 1675 & الصويرة & & 68,05 & 4230 & الحي & \\
\hline 7,53 & 7500 & الأحر ار & & 52,2 & 667,15 & بدرة & \\
\hline 5,74 & 1260 & الدبوني & \multirow{4}{*}{$\begin{array}{l}\overline{3} \\
\overline{\bar{z}}\end{array}$} & 43,63 & 3402 & شيخ سعد & \multirow{4}{*}{$\begin{array}{l}\overline{3} \\
\overline{3}\end{array}$} \\
\hline 5,54 & 1675 & العزيزية & & 28,24 & 6858,5 & النعمانية & \\
\hline 2,4 & 1200 & الشحيمية & & 27,03 & 1614,42 & جصان & \\
\hline 1,90 & 1277,64 & تاج الدين & & 26,10 & 8772,204 & الكوت & \\
\hline
\end{tabular}

المصدر : مديرية زر اعة واسط ، قسم الإحصاء ، بيانات غبر منشورة ،20 
خريطة (0)

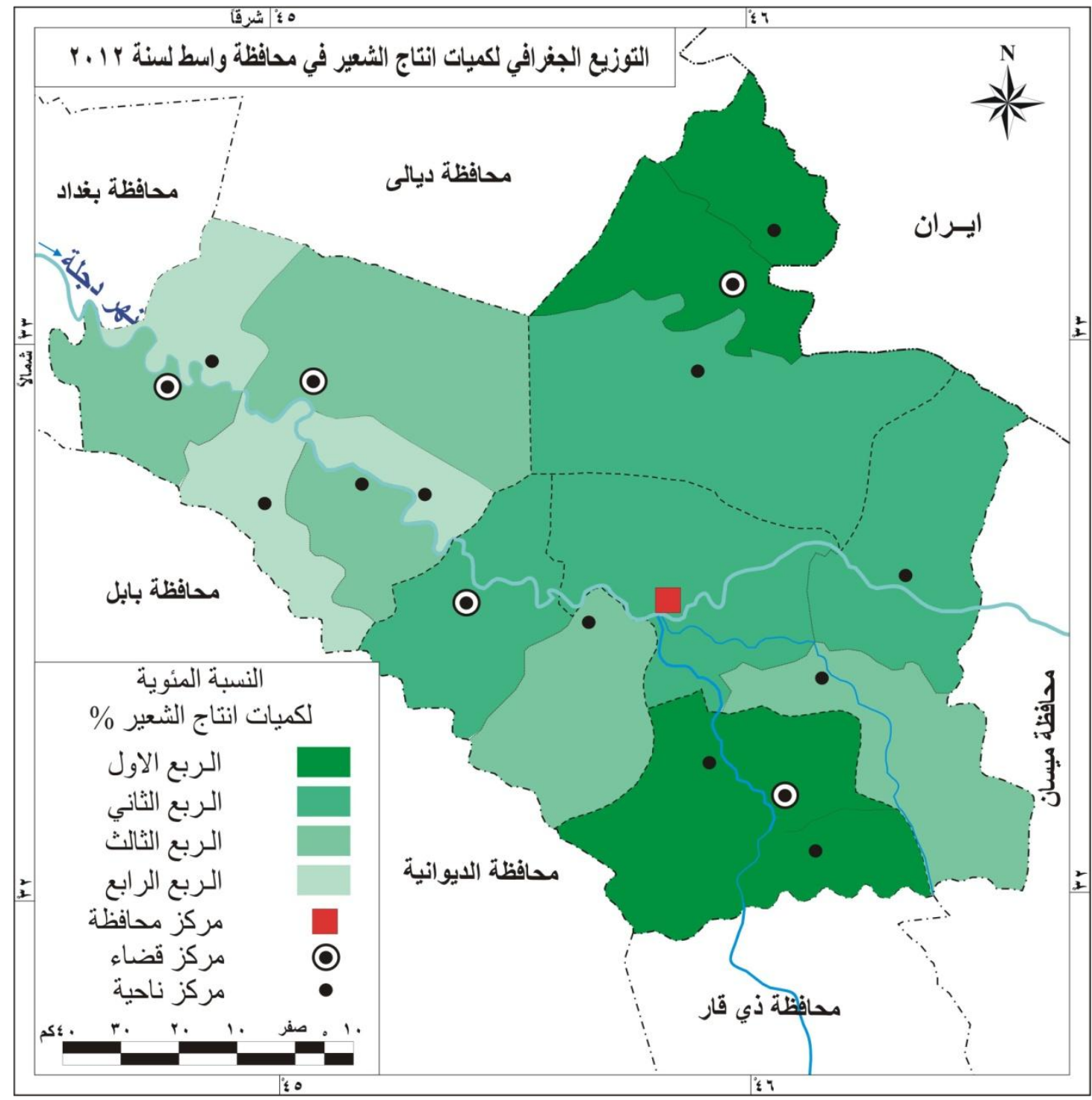

المصدر : مديرية زر اعة واسط ، قسم الإحصاء ، بيانات غير منشورة ،2012.

الربيع من شهر آذار وينم حصادها في أواخر شهر حزيران و الثانية تسمى العروة الخريفيةوتزرع في فصل الخريف في شهر تموز ويتم حصادها في شهر تثرين الأول ، وينطلب الدونم الواحد

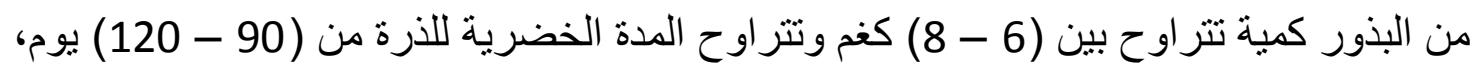

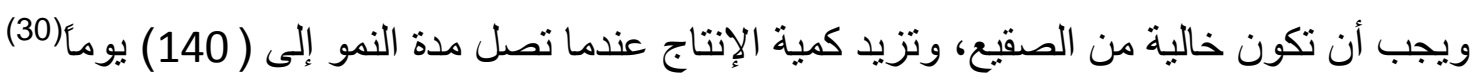

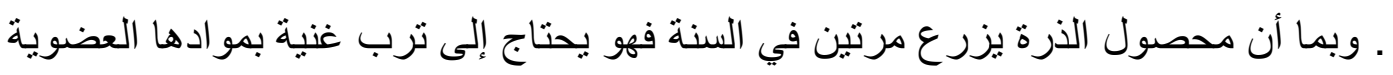


فتضاف إلى التربة أسمدة كيمياوية مركبة بمقدار (30) كغم / دونم وسماد اليوريا بمقدار (110)

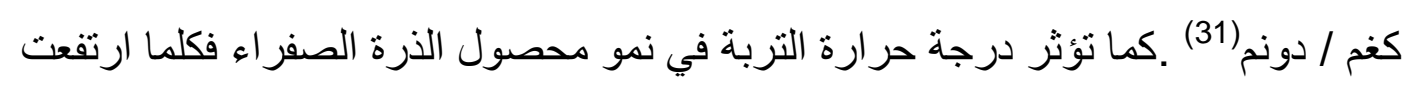

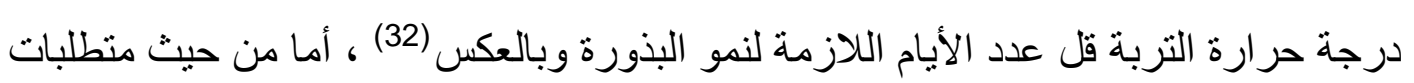

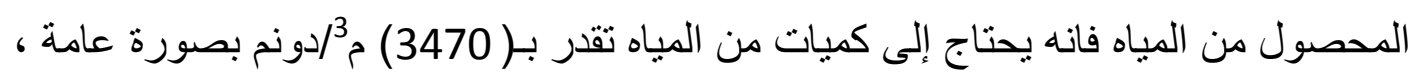
وتقلل الرطوبة في التربة من استطالة نباتات الذرة الصفر اء ومن ثم يؤثر على عملية التركيب

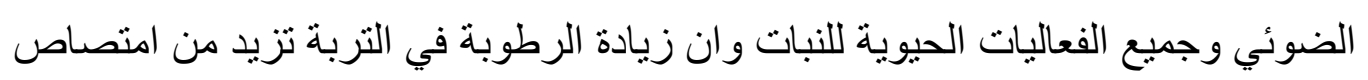

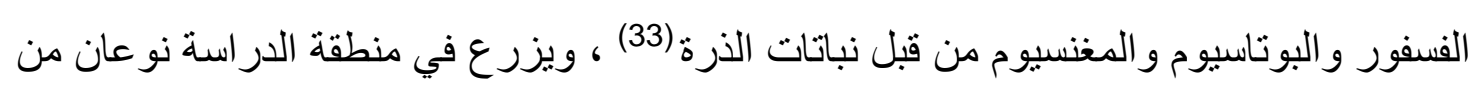

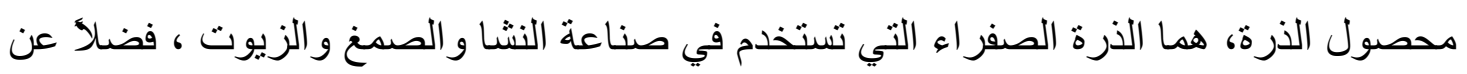

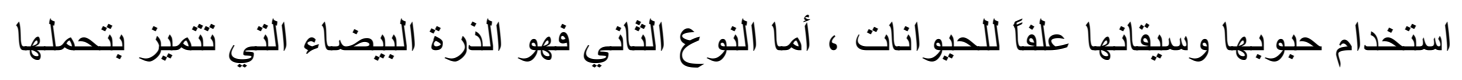

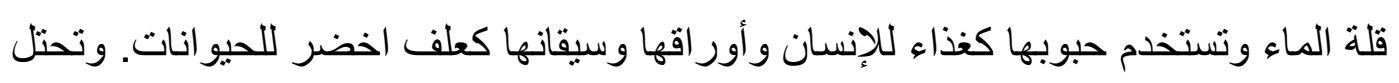

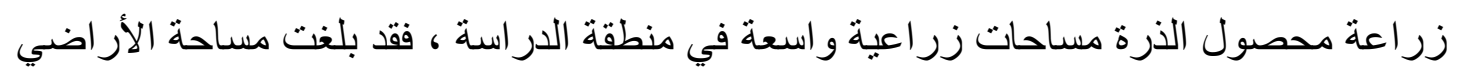

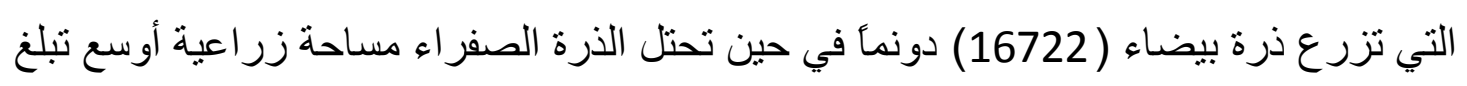

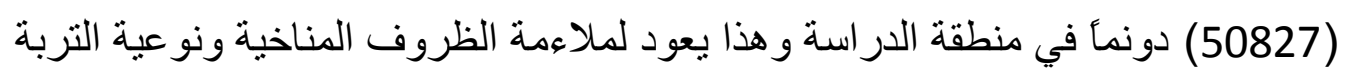

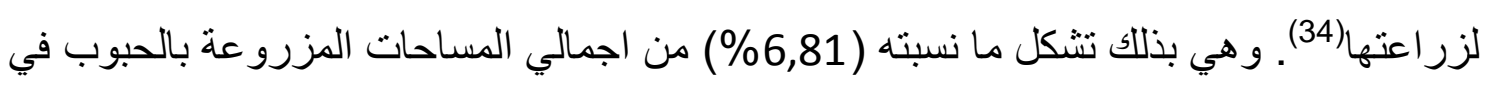
المحافظة .

ويظهر إقليم الذرة في توزيعه في مناطق محددة من جهات منطقة الدر اسة، و على الرغم من

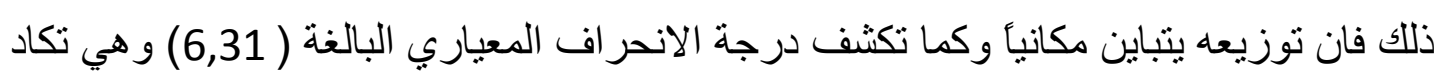
تساوي قيمة الوسط الحسابي لمساحة الذرة البالغة (4,63\%) وباستخدام طريقة الانحر اف الربعي

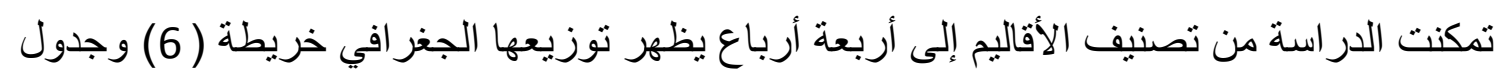

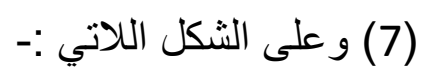


يأخذ هذا الربع توزيعاً جغر افياً متباينأ في مناطق عدة من المحافظة لتكون وحدة جغر افية غير

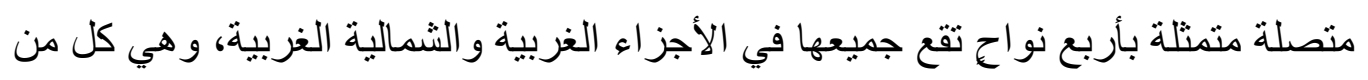

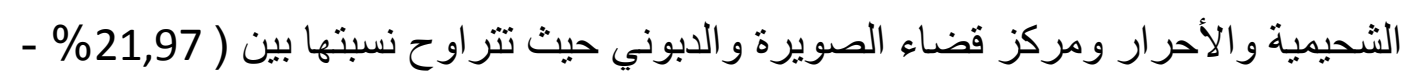
\%5,81) من مجموع المساحات المخصصة لزر اعة الحبوب ، أما بالنسبة لكميات الإتتاج فإنها

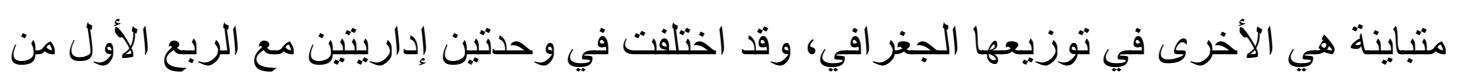
حيث المساحة وهما ناحية الثحيمية ومركز قضاء الصويرة حيث جاءت الأولى في الربع الثناني

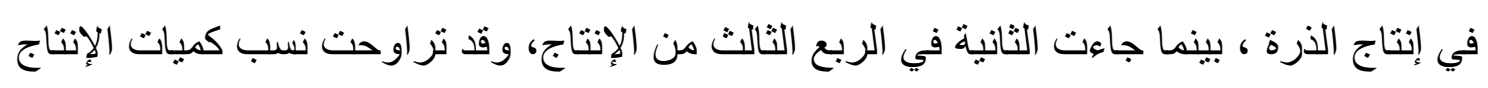

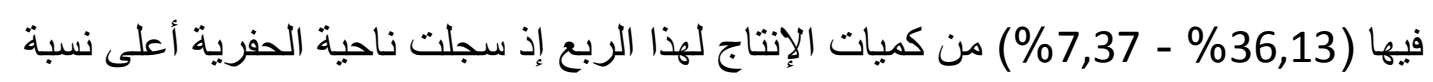

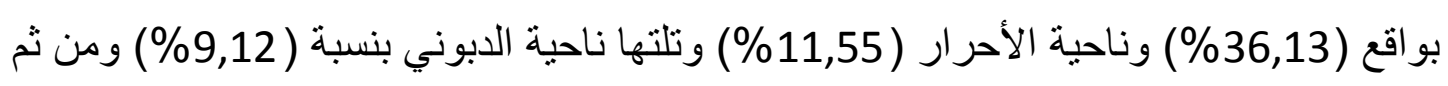

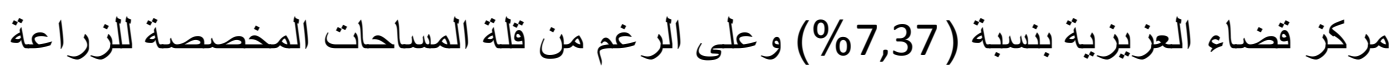

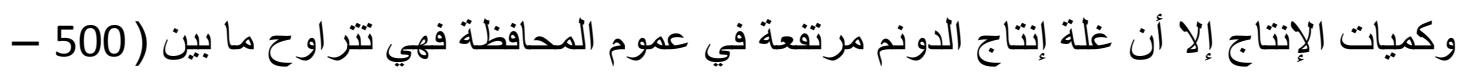

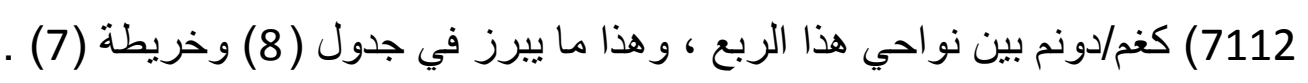

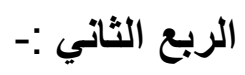

نظهر المساحات المخصصة لزر اعة الذرة في هذا الإقليم في أربع نو اح لا تكون وحدة

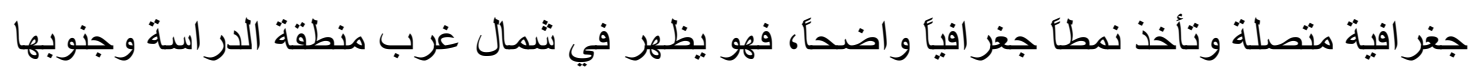

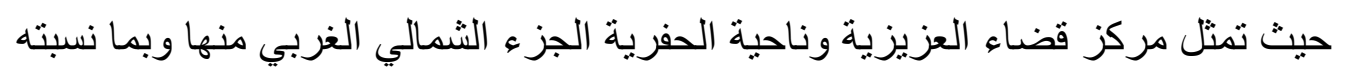
(5,66 و 4,6\%) على التو الي لكل منهما، بينما يظهر مركز قضاء الكوت في وسطها ومركز

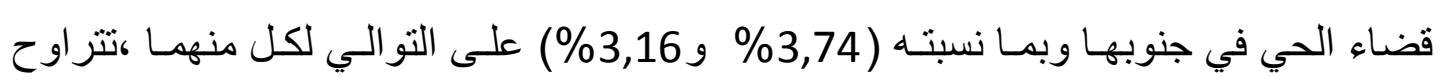

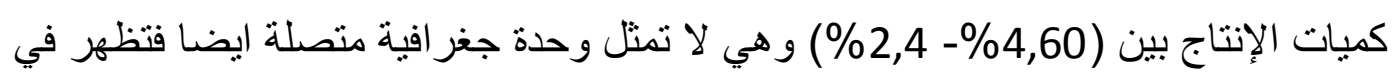

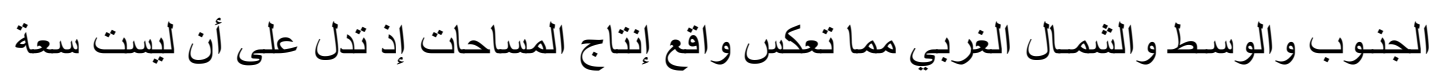
المساحة تعطي إنتاج اكبر بقدر ما تكون هناك ارتفاع في إنتاجية الغلة إذ سجلت معدلات غلتهاج تتراوح ما بين(500 - 1000) كغم / دونم. 
يشهر هذا الربع تر اجعأ في حجم المساحات المزرو عة بالذرة ، ويتوزع جغر افياً بأربع نواح شمال وغرب وجنوب منطقة الدر اسة، هي مركز قضاء بدرة و الزبيدية والبشائر ومركز

جدول (7)

التوزيع الربعي للمساحات المزرو عة بالذرة حسب نو احي منطقة الدر اسة لسنة 2012

\begin{tabular}{|c|c|c|c|c|c|c|c|}
\hline النسبة \% & المزنموعة الماحة & الوحدة الإدارية & & النسبة \% & المزروعة المساحة & الوحدة الإدارية & \\
\hline 0,56 & 45 & بدرة & \multirow{4}{*}{$\begin{array}{l}\overline{3} \\
\overline{3} \\
\overline{3}\end{array}$} & 21,97 & 20000 & الثحيمية & \multirow{4}{*}{$\begin{array}{l}\overline{3} \\
\bar{\lambda} \\
\bar{j}\end{array}$} \\
\hline 0,49 & 400 & الزبيدية & & 16,48 & 23000 & الأحر ار & \\
\hline 0,36 & 50 & البشائر & & 8,43 & 6050 & الصويرة & \\
\hline 0,14 & 120 & النعمانية & & 5,81 & 2500 & الدبوني & \\
\hline$\overline{\overline{0,9}}$ & 300 & المو فقية & \multirow{4}{*}{$\begin{array}{l}\overline{\overline{3}} \\
\overline{3} \\
\overline{\overline{2}}\end{array}$} & $\overline{5,66}$ & "4450 & العزيزية & \multirow{4}{*}{$\begin{array}{l}\overline{3} \\
\overline{3} \\
\overline{3}\end{array}$} \\
\hline 0,9 & 65 & و واسط & & 4,6 & 3415 & الحفرية & \\
\hline 0,8 & 40 & شيخ سعد & & 3,74 & 2500 & الكوت & \\
\hline 0,02 & 40 & جصان & & 3,16 & 572 & الحي & \\
\hline
\end{tabular}

المصدر : مديرية زر اعة واسط ، قسم الإحصاء ، بيانات غير منشورة ، 2012 
خريطة (†)

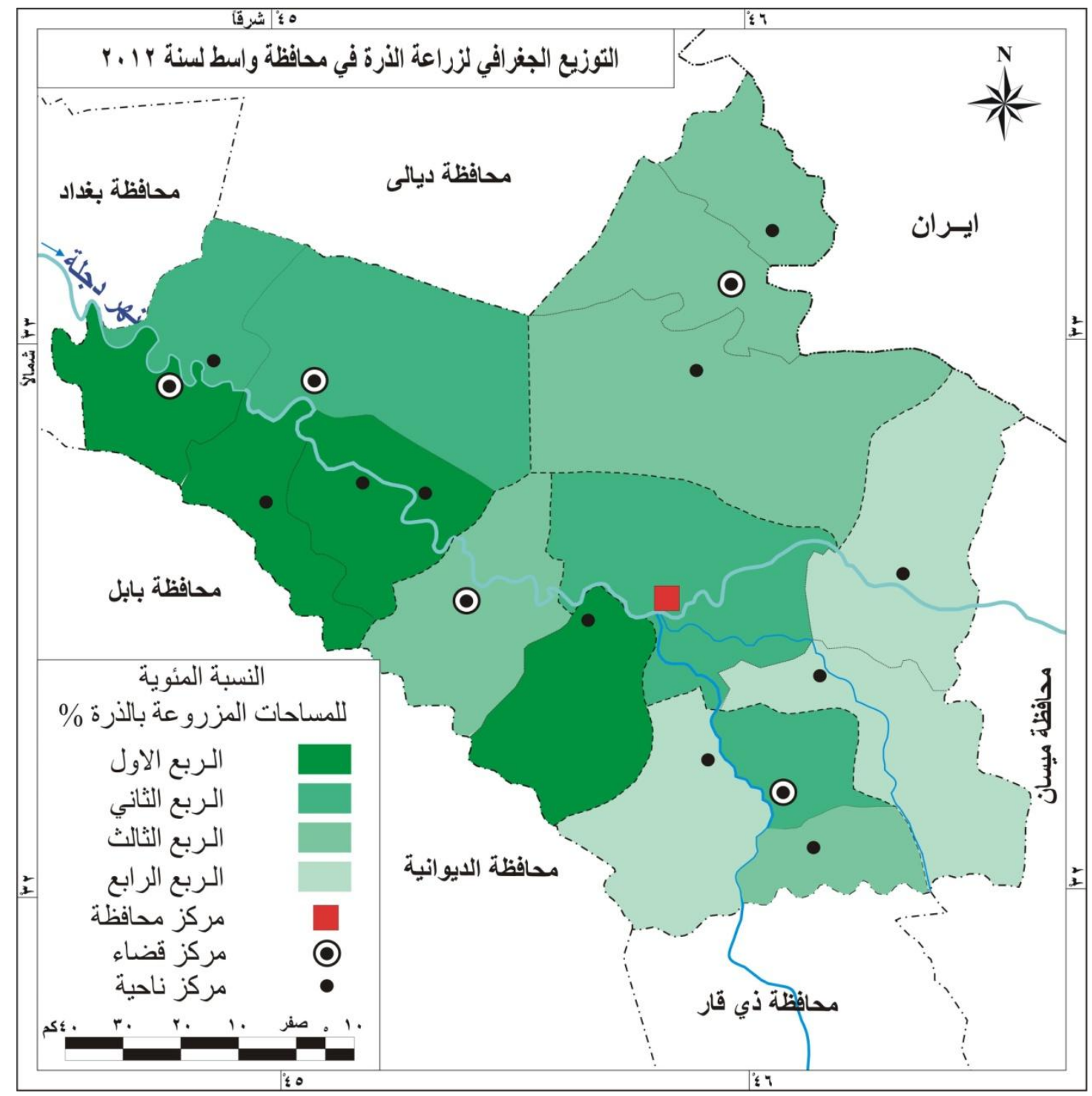

المصدر : مديرية زر اعة واسط ، قسم الإحصاء ، بيانات غير منشورة ، 2012.

قضاء النعمانية حيث تراوحت نسب مساحتها بين ( 0,56\% - 0,14\%) من مجموع المساحات المخصصة لزر اعة الحبوب فضلا عن انخفاض كميات إنتاجها التي تراوحت نسبها بين (1,19\% - 0,65\%) و على الرغم من اختلاف النواحي بين الربعين فأن مساحتها المخصصة لزر اعة الذرة 
تقل قلة واضحة وكذللك انخفاض كميات إنتاج الغلة التي تراوحت ما بين ( 500 - 55,3) كغم /

$$
\text { دونم } 0
$$

$$
\text { الربع الرابع :- }
$$

يمثل هذا الربع اقل جهات منطقة الدراسة في زر اعة الذرة من خلال قلة المساحات المزروعة

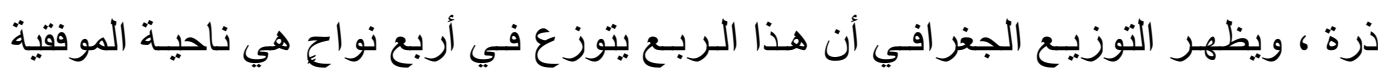

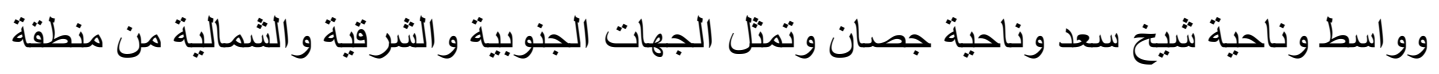

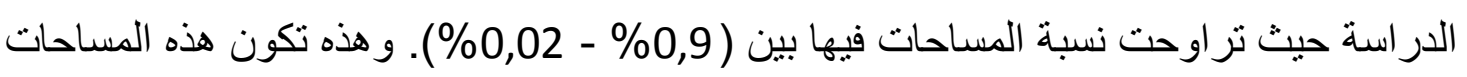

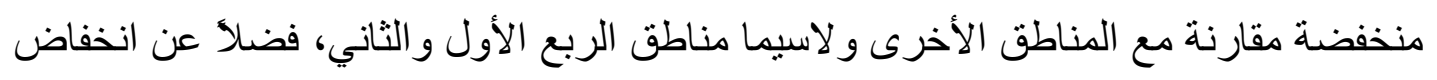

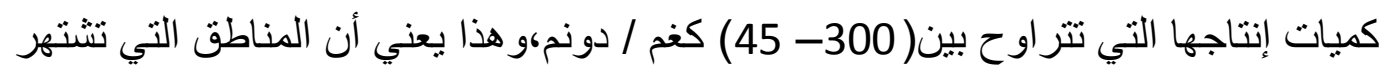
بزر اعة الذرة في الجهات الغربية وبمساحات كبيرة آخذه بالقلة في المناطق الجنوبية 0

النتائج

1- توصل البحث الى ان هناللك تباين في مساحة اقليم زر اعة الحبوب بين الوحدات الادارية في

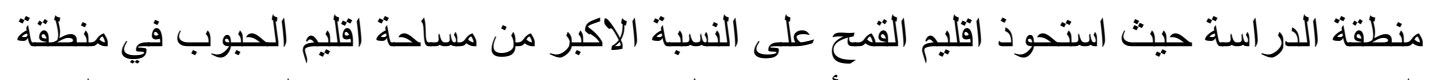

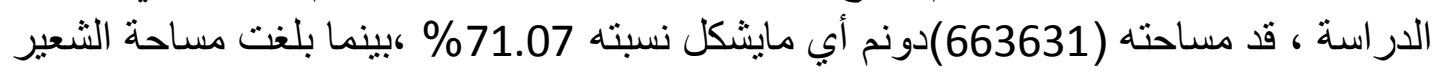

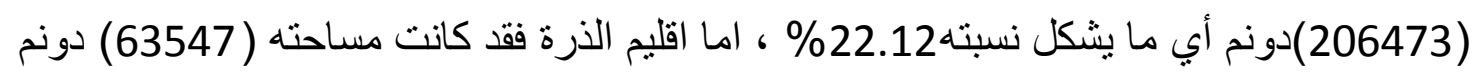
أي ما يشكل نسبه 6.81\% من مجموع مساحة اقليم زر اعة الحبوب في محافظة واسط.

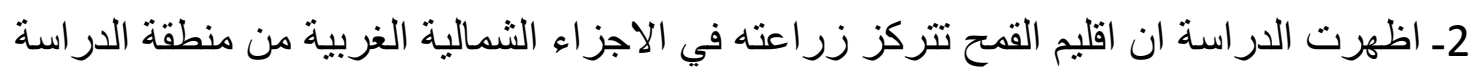

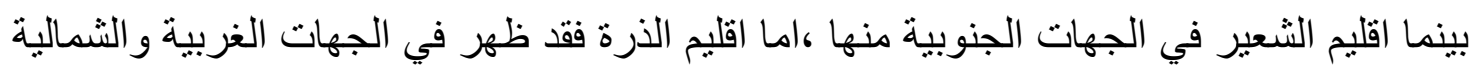
الغربيىة منها.

3ـ اظهرت الدراسة ان هناك ارتفاع في كميات الانتاج ومعدل الغلة للاونم في الجهات الثمالية

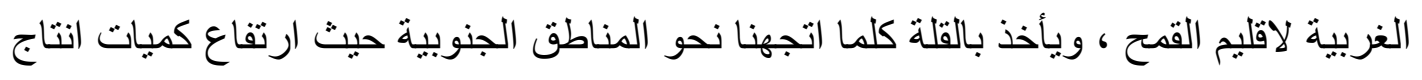




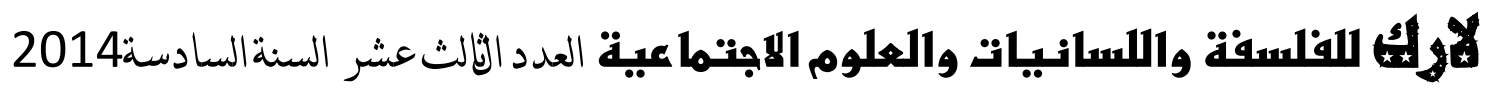

جدول (8) (8)

التوزيع الربعي لكميات إنتاج الذرة حسب نو احي منطقة الدراسة لسنة2012

\begin{tabular}{|c|c|c|c|c|c|c|c|}
\hline النسبة \% & المزنموعة المساحة & الوحدة الإدارية & & النسبة \% & المزنم المساحة / & الوحدة الإدارية & \\
\hline 1,19 & 50 & البشائر & \multirow{4}{*}{$\begin{array}{l}\overline{3} \\
\overline{3} \\
\overline{3}\end{array}$} & 36,13 & 24290,5 & الحفرية & \multirow{4}{*}{$\begin{array}{l}\overline{3} \\
\overline{3} \\
\overline{3}\end{array}$} \\
\hline 0,99 & 90 & الموفقية & & 11,55 & 11500 & الأحر ار & \\
\hline 0,84 & 336 & الصويرة & & 9,12 & 2000 & الدبوني & \\
\hline 0,65 & 180 & الزبيدية & & 7,37 & 2225 & العزيزية & \\
\hline 0,38 & 30 & شيخ سعد & \multirow{4}{*}{$\begin{array}{l}\overline{3} \\
\overline{3} \\
\overline{2}\end{array}$} & 4,60 & 286 & الحي & \multirow{4}{*}{$\begin{array}{l}\overline{3} \\
\overline{3} \\
\overline{3}\end{array}$} \\
\hline 0,37 & 90 & النعمانية & & 4,46 & 1500 & الكوت & \\
\hline 0,33 & 20 & جصان & & 2,63 & 35 & بدرة & \\
\hline 0,16 & 55 & و واسط & & 2,4 & 1200 & الثحيمية & \\
\hline
\end{tabular}


خريطة (ل)

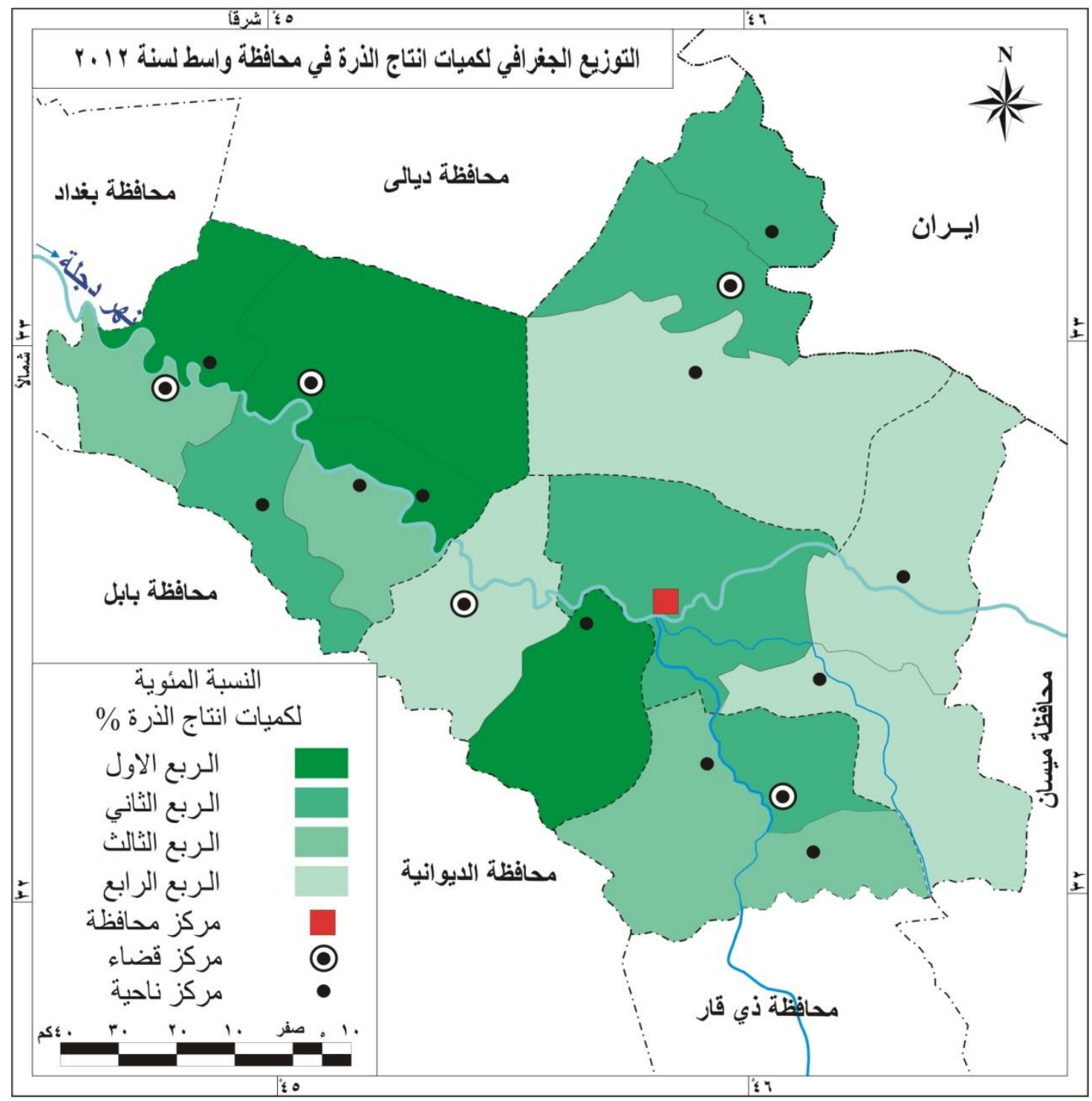

المصدر : مديرية زر اعة واسط ، قسم الإحصاء ، بيانات غير منشورة ، 2012. الهو امش و المصادر

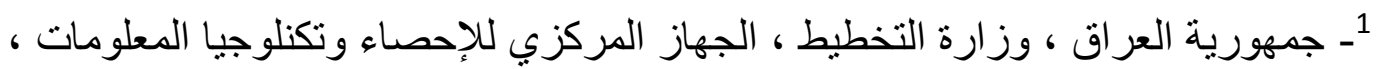

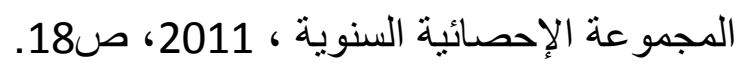




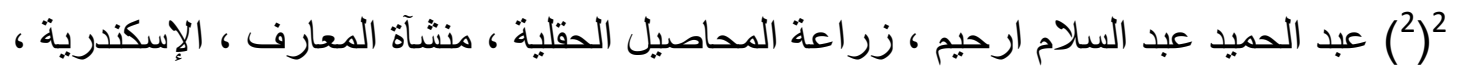

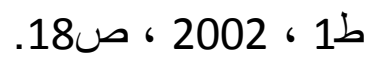

(3) محمد خميس الزوكة ، الجغر افية الاقتصادية ، دار الجامعات المصرية ، القاهرة ، 1977 ، 0 ص229 0

(4) عبد الله قاسم الفخري ، الزر اعة الجافة ، مطبعة جامعة الموصل ، الموصل ، 1981 ، 0 ص309 0

(4) L-A-Hoffmam, Economic geogeaphy, Roland press, co., new York, 1965, p.152.

$$
\begin{aligned}
& \text { (6) كمال صالح كزكوز ، مصدر سابق ، ص104 } 0 \\
& 0 \text { (7) مديرية زر اعة محافظة واسط ، بيانات غير منشورة ، } 2012 \\
& 0 \text { 222 } 0
\end{aligned}
$$

(9) حبيب راضي طلفاح ، تحليل العلاقات المكانية لزر اعة المحاصيل في محافظة و اسط ، مجلة ، 2007 ، البحوث الجغر افية ، العدد8 ، 2007 ، ص13 0

(10) حازم جو اد كاظم العارضي ، مصدر سابق ، ص34 0

0 30 0

(12) علي محمد المياح ، الجغر افية الزراعية ، مطبعة الارشاد ، بغداد ، 1976 ، ص52 0 0 (ر) 2012 مديرية زر اعة واسط ، قسم الاحصاء ، بيانات غير منشورة ،

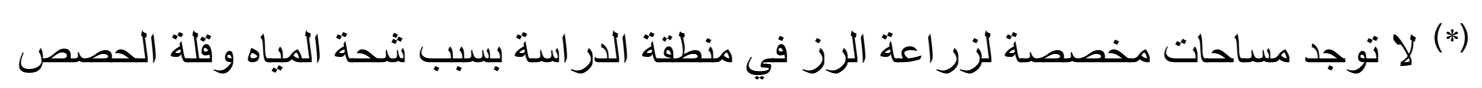
المائية المخصصة لزر اعته في فصل الصيف

(14) مديرية زر اعة واسط ، قسم الإحصاء ، بيانات غير منشورة ، 2012 .

(*) تمثل نسبة المساحة المزرو عة بالقمح من إقليم الحبوب على مستوى كل ناحية فعندما تجمع مع لكع

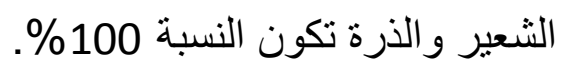

(المصدر نفسأ 
(المصدر نفسهاه

(17) مديرية زر اعة واسط ، قسم الإحصاء ، بيانات غير منشورة ، 2012.

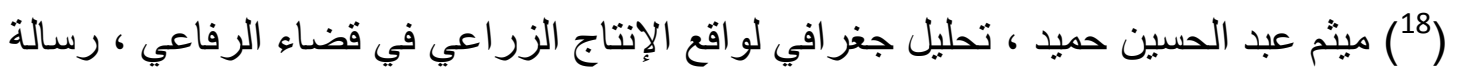

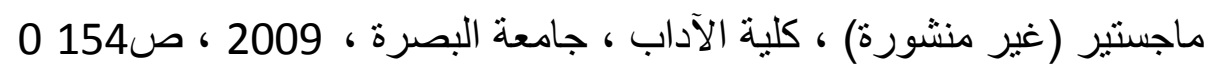

( 19 (19 مصن احمد الجنابي ،يونس عبد القادر علي ، مدخل في إنتاج الدحاصيل الحقلية ، دار ،

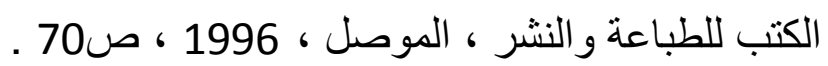

(20) كامل سعيد جو اد ، عرفان شاكر ، مصدر سابق ، ص145-158 0

( ) محمد عبد السعيدي ، أساسيات انتاج المحاصيل الحقلية ، مطبعة دار الحرية ، بغداد ، 1978

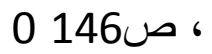

(22) وفقي شاكر الثماع ، عبد الحمبد اليونس ، الدحاصيل الحبوبية والبقولية ، مطبعة جامعة

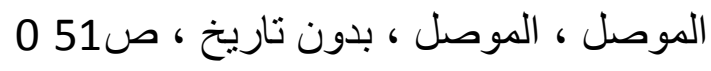

0 (23) مديرية زر اعة واسط ، قسم الاحصاء ، بيانات غير منشورة ، 2012 (24) عبد الحميد عبد السلام ارحيم ، مصدر سابق ، صل 0

0 ( 2012 مديرية زراعة واسط ، قسم الاحصاء ، بيانات غير منشورة ،

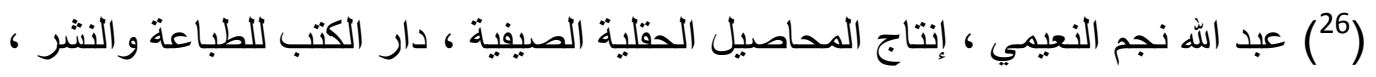

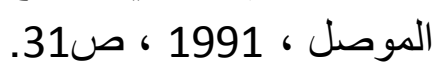

(27) عبد الحميد احمد اليونس ، محاصيل الحبوب ، دار الكتب للطباعة والنشر ، الموصل ، 1087 1987 ، صن صن 0

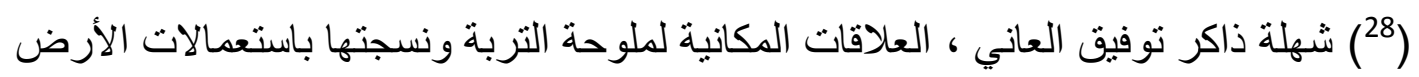

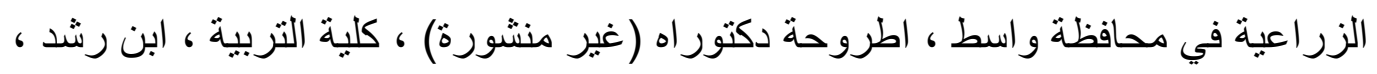

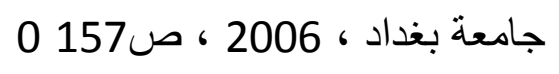

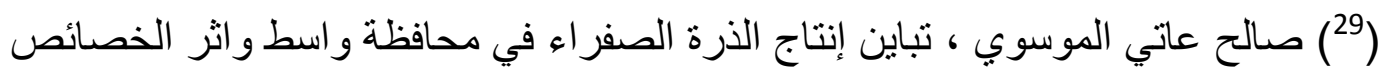

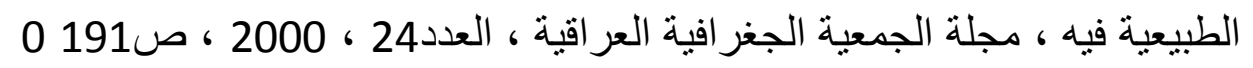


(29) L-A-Hoffmam, Economic geogeaphy, Roland press, co., new York, 1965, p.152

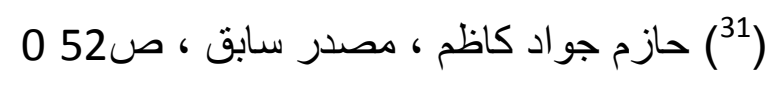

(31) World Meteorological, Regional trading Center, Boghdad, April, 1426, 1984, P.4 .

(32) J.S.Bayer Leaf on Largement and Metabelic Rateincon, soy been and Sanflowers at variour Least water Potential Plant Physical, 1970,P.233 .

$$
0 \text { (34) مديرية زر اعة واسط ، قسم الاحصاء ، بيانات غير منشورة ، } 2012
$$

